\title{
Nitrogen transformations along a shallow subterranean estuary
}

\author{
Mathilde Couturier ${ }^{1,2}$, Gwendoline Tommi-Morin ${ }^{1,2}$, Maude Sirois ${ }^{1,3}$, Alexandra Rao ${ }^{3}$, Christian Nozais ${ }^{2}$, and \\ Gwénaëlle Chaillou ${ }^{1,2}$ \\ ${ }^{1}$ Canada Research Chair on the Geochemistry of Coastal Hydrogeosystems, BOREAS, group on Nordic System, \\ Département de Biologie, Chimie, Géographie, Université du Québec à Rimouski, Rimouski, G5L3A1, Canada \\ ${ }^{2}$ Département de Biologie, Chimie, Géographie, Université du Québec à Rimouski, Rimouski, G5L3A1, Canada \\ ${ }^{3}$ Institut des sciences de la mer de Rimouski, Université du Québec à Rimouski, Rimouski, Quebec, G5L 3A1, Canada
}

Correspondence to: Mathilde Couturier (mathilde.couturier@uqar.ca)

Received: 10 December 2016 - Discussion started: 23 December 2016

Revised: 2 June 2017 - Accepted: 7 June 2017 - Published: 11 July 2017

\begin{abstract}
The transformations of chemical constituents in subterranean estuaries (STEs) control the delivery of nutrient loads from coastal aquifers to the ocean. It is important to determine the processes and sources that alter nutrient concentrations at a local scale in order to estimate accurate regional and global nutrient fluxes via submarine groundwater discharge (SGD), particularly in boreal environments, where data are still very scarce. Here, the biogeochemical transformations of nitrogen $(\mathrm{N})$ species were examined within the STE of a boreal microtidal sandy beach located in the Magdalen Islands (Quebec, Canada). This study revealed the vertical and horizontal distribution of nitrate $\left(\mathrm{NO}_{3}^{-}\right)$, nitrite $\left(\mathrm{NO}_{2}^{-}\right)$, ammonia $\left(\mathrm{NH}_{4}^{+}\right)$, dissolved organic nitrogen (DON) and total dissolved nitrogen (TDN) measured in beach groundwater during four spring seasons (June 2011, 2012, 2013 and 2015) when aquifer recharge was maximal after snowmelt. Inland groundwater supplied high concentrations of $\mathrm{NO}_{x}$ and DON to the STE, whereas inputs from seawater infiltration were very limited. Non-conservative behaviour was observed along the groundwater flow path, leading to low $\mathrm{NO}_{x}$ and high $\mathrm{NH}_{4}^{+}$concentrations in the discharge zone. The long transit time of groundwater within the beach ( $\sim 166$ days), coupled with oxygen-depleted conditions and high carbon concentrations, created a favourable environment for $\mathrm{N}$ transformations such as heterotrophic and autotrophic denitrification and ammonium production. Biogeochemical pathways led to a shift in nitrogen species along the flow path from $\mathrm{NO}_{x}$-rich to $\mathrm{NO}_{x}$-poor groundwater. An estimate of SGD fluxes of $\mathrm{N}$ was determined to account for biogeochemical transformations within the STE based on a $\mathrm{N}$-species inventory and Darcy's flow. Fresh inland ground-
\end{abstract}

water delivered $37 \mathrm{~mol} \mathrm{NO}_{x} \mathrm{yr}^{-1}$ per metre of shoreline and $63 \mathrm{molDON} \mathrm{m}{ }^{-1} \mathrm{yr}^{-1}$ to the STE, and $\mathrm{NH}_{4}^{+}$input was negligible. Near the discharge zone, the potential export of $\mathrm{N}$ species was estimated around 140, 1.5 and $33 \mathrm{~mol} \mathrm{yr}^{-1}$ per metre of shoreline for $\mathrm{NH}_{4}^{+}, \mathrm{NO}_{x}$ and DON respectively. In contrast to the fresh inland groundwater, the $\mathrm{N}$ load of beach groundwater near the discharge zone was dominated by $\mathrm{NH}_{4}^{+}$ and DON. Our study shows the importance of tidal sands in the biogeochemical transformation of the terrestrial $\mathrm{N}$ pool. This local export of bioavailable $\mathrm{N}$ probably supports benthic production and higher trophic levels leading to its rapid transformation in surface sediments and coastal waters.

\section{Introduction}

Land-ocean interfaces are critical transition zones that may affect the ecology and quality of coastal ecosystems (Schlacher and Connolly, 2009). Chemical constituents in submarine groundwater discharge (SGD) are now widely recognized to have a significant impact on coastal ecosystems (Knee and Jordan, 2013; McCoy and Corbett, 2009; Null et al., 2012; Slomp and Van Cappellen, 2004). SGD is conventionally defined as "any flow of water out across the seafloor without regards to its composition and its origin" (Burnett et al., 2006). Thus, before entering coastal waters, fresh groundwater travels through a shallow subterranean estuary (STE) (Moore, 1999), a region where mixing between fresh and marine groundwater promotes biogeochemical processes that can lead to rapid changes in nutrient concentrations and induce non-conservative input or re- 
moval (Gonneea and Charette, 2014). The STE supports extensive chemical reactions near the discharge interface and is often assumed to be a non-steady-state system (Kroeger and Charette, 2008). Continental factors (e.g. local hydrogeology, recharge, precipitation) as well as marine factors (e.g. tidal and wave pumping, hydrography, and density) induce temporal and spatial variability in biogeochemical conditions (see Santos et al., 2012, and references therein). The mixing zone is subject to oscillating conditions, with rapid changes in oxygen saturation, redox potential and organic matter input controlled by tidal stage and amplitude, sea level and seasonal water table fluctuations (Abarca et al., 2013; Gonneea et al., 2013; Heiss and Michael, 2014; Robinson et al., 2014). These physical processes are likely to impact the distribution and biogeochemical reactivity of many dissolved constituents (Beck et al., 2007; Kroeger and Charette, 2008). In this context, the STE either can be a source of nutrients or act as a barrier and limit nutrient discharge to coastal environments. Assessing the role of the STE in nutrient transformations is crucial to better quantifying global chemical fluxes via SGD (Moore, 2010).

Rivers have long been considered the main conveyors of $\mathrm{N}$ to the ocean (Seitzinger et al., 2005, and references therein). Beusen et al. (2013) recently provided evidence that SGD also plays a major role in regional and global marine $\mathrm{N}$ cycles. $\mathrm{N}$ loads from SGD to nearshore ecosystems have been estimated to be $4 \mathrm{Tg} \mathrm{N} \mathrm{yr}^{-1}$ (Voss et al., 2013), and the role of SGD in coastal eutrophication has also been demonstrated (Valiela et al., 1990). These $\mathrm{N}$ loads may be an important factor in the development of harmful algal blooms in coastal waters (Anderson et al., 2008; Glibert et al., 2014). Fresh groundwater is often rich in nutrients and other materials from anthropogenic inputs due to coastal development (agriculture, urbanization) (Howarth and Marino, 2006; Null et al., 2012; Rocha et al., 2015), and models predict a $20 \%$ increase in N loads from SGD within the next few decades due to coastal development (Beusen et al., 2013).

Estimates of nutrient loads from the SGD to the coastal ocean have often been based on nutrient concentrations in fresh groundwater, with the assumption that nutrient transport through the STE is conservative (Burnett et al., 2006). However, numerous studies have demonstrated that concentrations of dissolved $\mathrm{N}$ change throughout the STE because of biological and chemical reactions (Beck et al., 2007; Loveless and Oldham, 2010; Moore, 2010; Santos et al., 2009). Variations in oxygen and organic matter input along the hydraulic gradient lead to a combination of heterotrophic processes that can enhance or attenuate the export of $\mathrm{N}$ to the coastal ocean (Santoro, 2010). For example, in the Gulf of Mexico (Turkey Point, Florida), the STE acts as a source of ammonium because remineralization of marine organic matter throughout the STE provides nutrients to the SGD exported to the embayment (Santos et al., 2008). In Waquoit Bay (Cape Cod, Massachusetts), Kroeger and Charette (2008) demonstrated that ammonium accumu- lates in the STE because remineralization of organic matter transported by marine and fresh groundwater outpaces nitrification. In contrast, based on the $\mathrm{N}$ attenuation observed in a shallow STE due to denitrification (Cockburn Sound, Australia), Loveless and Oldham (2010) calculated nitrate loads to coastal waters that were 1-2 times lower than previous estimates based on nutrient concentrations from fresh groundwater. As these studies show, ignoring non-conservative mixing can lead to an over- or underestimation of nutrient loads to coastal waters (Beck et al., 2007).

STEs are transient systems where steady state and thus the classical diagenetic sequence of redox reactions are rarely achieved (Sundby, 2006). In transient systems, diagenetic reactions reflect redox oscillations and environmental conditions far from steady state. Redox oscillations, with alternating oxic and anoxic conditions in sediments, allow coupled nitrification-denitrification to take place in the same location within the sediment (Aller, 1994). Alternative pathways of nitrate reduction, such as dissimilatory nitrate reduction to ammonium (DNRA) and Anammox, have also been reported in the STE (Erler et al., 2014; Kroeger and Charette, 2008; Rocha et al., 2009; Sáenz et al., 2012). Many of these processes transform dissolved inorganic nitrogen (DIN) and dissolved organic nitrogen (DON) along the groundwater flow path. DON is assumed to be from natural rather than anthropogenic sources and is often neglected (Hansell and Carlson, 2014). Nevertheless, DON concentrations can be high in SGD and should be considered (Kroeger et al., 2007; Santos et al., 2014).

Martinique Beach, located in the Magdalen Islands (Quebec, Canada) at the southern limit of the boreal climatic zone, is exposed to little or no external contamination. Site-specific studies in boreal and cold environments are still scarce, and climate and hydrology change rapidly in cold climates (Hinzman et al., 2005). Thus nutrient fluxes by SGD to the coastal ocean in boreal regions and their contribution at local and global scales remain to be elucidated. The objective of this 4-year study was to investigate the spatial and temporal variation of $\mathrm{N}$ species (inorganic and organic $\mathrm{N}$ ) through a shallow boreal STE, from inland groundwater to coastal ocean. SGD fluxes of the different $\mathrm{N}$ species that are discharged to coastal waters by shallow groundwater at this specific-site were also estimated.

\section{Materials and methods}

\subsection{Study area}

Martinique Beach is located on the main island of the Magdalen Islands archipelago in the Gulf of St. Lawrence (Quebec, Canada; Fig. 1). The Martinique Beach system originates from a recent transgression sequence. Rapid rates of sea-level rise along the Atlantic coast of Canada over the middle to late Holocene buried the unconfined Permian sandstone aquifer, which is now covered by tidal sediment 

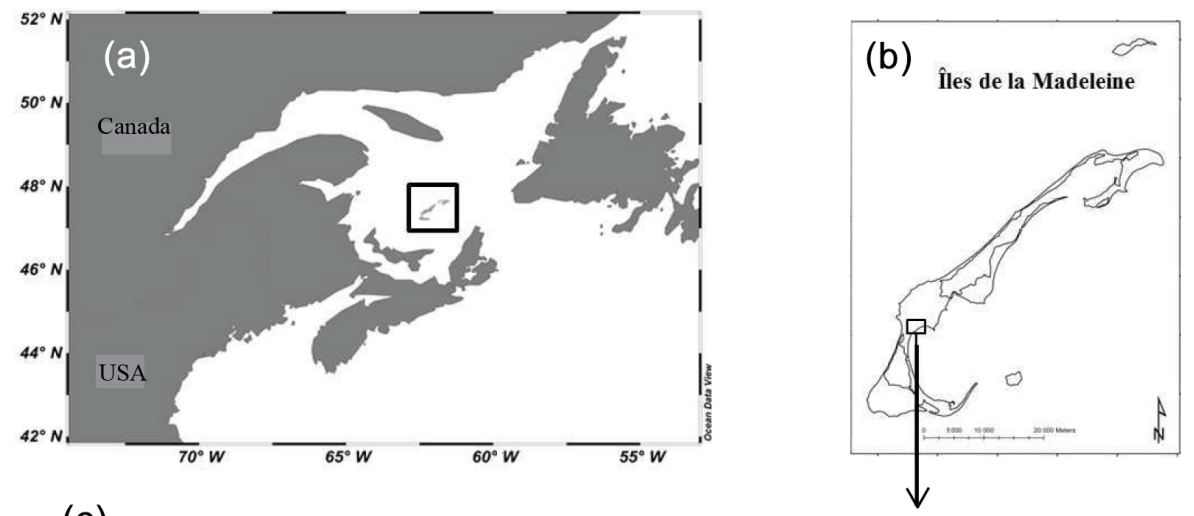

(c)

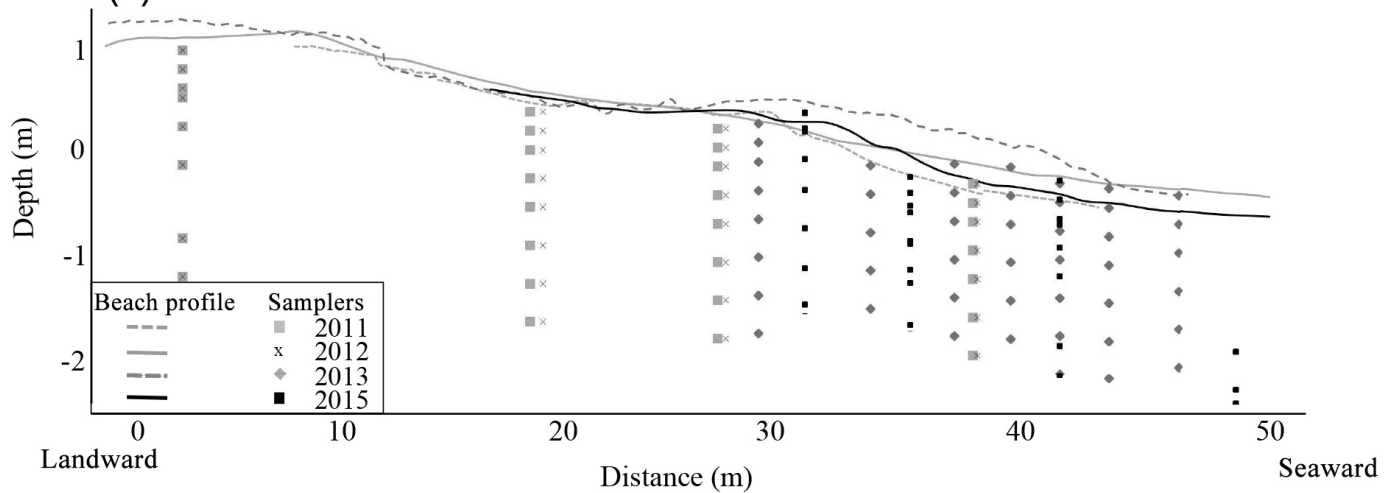

Figure 1. Position of the study site in the Magdalen Islands (Quebec, Canada) (a, b). Beach profile of Martinique Beach in 2011, 2012, 2013 and 2015; beach profiles were determined using a DGPS; locations of sampling sites (2011-2013, 2015) along the sandy beach transect; depths are relative to mean sea level (i.e. $0 \mathrm{~m}$ is mean sea level) (c).

(Gehrels, 1994; Scott et al., 1995a, b). The site experiences semi-diurnal tides with a mean range of $0.8 \mathrm{~m}$ and a maximum range of $1.7 \mathrm{~m}$ during spring tide. The archipelago has no rivers; thus the aquifer recharge is only from rain and snow, with the highest recharge during spring snowmelt. The mean yearly recharge is about $230 \mathrm{~mm}$ (Madelin'Eau, 2004). Because groundwater constitutes the only source of drinking water in the archipelago, the hydrogeology is well known, and the aquifer constantly monitored (Chaillou et al., 2012; Madelin'Eau, 2007, 2009, 2011). Since anthropogenic pressures like urbanization and agriculture are limited in the archipelago, the main sources of $\mathrm{N}$ contamination are from residential and recreational areas. Therefore, Martinique Beach is an ideal system in which to study $\mathrm{N}$ transformations in a boreal microtidal subterranean estuary.

The Martinique Beach STE acts as a shallow unconfined aquifer at the nearshore limit of the Permian aquifer; it releases both fresh and recirculated saline groundwater to the coastal embayment (Chaillou et al., 2016). It is a low-energy beach under a microtidal regime (Jackson et al., 2002; Masselink and Short, 1993). The upper centimetres $(20 \mathrm{~cm})$ of the beach consist of marine sands with a median particle size of $0.30 \mathrm{~mm}$ (silt content $<5 \%$ ), mainly composed of quartz $(95 \%)$. The hydraulic conductivity of this sedimentary unit is about $11.40 \pm 4.40 \mathrm{~m} \mathrm{~d}^{-1}$ (Chaillou et al., 2016). Lower hydraulic conductivity was measured in the underlying sandstone aquifer ( $\mathrm{K} \sim 1.80 \mathrm{~m} \mathrm{~d}^{-1}$; Madelin'Eau, 2007), which is composed of fine silicate and aluminosilicate sands with $\mathrm{Fe}$ coated silicate grains (Chaillou et al., 2014). These two layers are organic-poor (total organic carbon $([\mathrm{TOC}])<0.20 \%$ weight percent (wt) and total nitrogen $[\mathrm{TN}]<0.10 \mathrm{wt} \%$; Chaillou et al., 2014). In the landward part of the beach, however, an old-age soil horizon dated to $\sim 900 \mathrm{BP}\left({ }^{14} \mathrm{C}\right.$ dating; Juneau, 2012) occurs a few centimetres below the beach surface. This horizon is carbon-rich ([TOC] $>20 \mathrm{wt} \%$ ) but has a low nitrogen content $([\mathrm{TN}]<0.50 \mathrm{wt} \%$; Chaillou et al., 2014).

In the Magdalen Islands, the snowmelt leads to a high water table from April to June in the Permian sandstone aquifer (Madelin'Eau, 2004) and in the adjacent beach aquifer (Chaillou et al., 2016). Under these hydrologic conditions, the saline circulation cell and its associated mixing zone are spatially limited, and the inland hydraulic gradient is the main control of total SGD (Heiss and Michael, 2014; Robinson et al., 2007a). Based on the stable isotopes of water along the STE, Chaillou et al. (2017) confirmed the contribution of only two water endmembers (i.e. fresh meteoric groundwater and seawater) and the absence of additional sep- 
tic tank seepages. They also highlighted the high contribution of fresh groundwater and the limited infiltration of seawater in shallow beach groundwater. The regional seaward fresh groundwater flow ( $Q_{\text {inland }}$ ) of about $0.021 \mathrm{~m}^{3} \mathrm{~s}^{-1}$ was estimated based on mean and multi-annual regional water table levels from municipal wells (Chaillou et al., 2016). $Q_{\text {inland }}$ is then the theoretical inland groundwater export from the Permian sandstone aquifer to Martinique Beach. At Martinique Beach, fresh groundwater flow was also evaluated based on a mean hydraulic gradient through the $50 \mathrm{~m}$ length of the beach. This specific flow ( $\left.Q_{\text {beach }}\right)$ was $0.029 \mathrm{~m}^{3} \mathrm{~s}^{-1}$, suggesting that fresh inland groundwater flux contributes to at least $70 \%$ of the water flow discharging to the coastal waters.

\subsection{Groundwater sampling}

Sampling was carried out in June 2011, 2012, 2013 and 2015 along a $50 \mathrm{~m}$ cross-shore transect. In 2011 and 2012, groundwater samples were collected in the landward part of the STE. In 2013 and 2015, we focused on the intertidal and discharge zone, where fresh meteoric groundwater comes in contact with recirculated seawater. Groundwater extraction was done using multi-level samplers in $2.5 \mathrm{~m}$ long PVC pipes (Fig. 1), similar to those described by Martin et al. (2003). Groundwater was collected at 10, 30, 50, $80,100,150,190$ and $230 \mathrm{~cm}$ below the beach surface. Samplers were re-inserted at the same locations each year using differential GPS (DGPS) coordinates. To allow sediments around the samplers to reach equilibrium, sampling started 2 days after their insertion. Groundwater was sampled using a peristaltic pump, and physico-chemical parameters $(\mathrm{pH}$, temperature, oxygen, salinity) were measured directly using an online flow cell with a calibrated multi-parameter probe (600QS, YSI Inc.). Oxygen measurements are not available for 2015, due to sensor malfunction. After stabilization of physico-chemical parameters, all groundwater samples were filtered through a $0.2 \mu \mathrm{m}$ polypropylene capsule filter. Samples for nutrient analyses $\left(\mathrm{NH}_{4}^{+}, \mathrm{NO}_{3}^{-}\right.$and $\left.\mathrm{NO}_{2}^{-}\right)$were stored in acid-washed polyethylene tubes that were rapidly frozen for later analysis; samples for total dissolved iron were stored at $4{ }^{\circ} \mathrm{C}$ in $50 \mathrm{~mL}$ acid-washed polyethylene tubes and acidified with $50 \mu \mathrm{L}$ of $10 \% \mathrm{HNO}_{3}$; and total dissolved nitrogen (TDN) samples were stored in baked $7 \mathrm{~mL}$ vials and acidified with $25 \mu \mathrm{L}$ of high-purity $10 \% \mathrm{HCl}$. TDN measurements were only performed in 2012. Groundwater endmember samples were collected in the manner described above from four private and municipal wells (two or three replicates per well) located 50 to $2000 \mathrm{~m}$ landward of the most inland sampler in the sandstone aquifer. Seawater endmember samples $(\mathrm{N}=6)$ were collected about $50 \mathrm{~cm}$ above the seabed using a submersible pump at about $900 \mathrm{~m}$ offshore in Martinique Bay.

\subsection{Chemical analyses}

$\mathrm{NH}_{4}^{+}$samples were measured by flow injection gas exchange-conductivity analysis based on the method described by Hall and Aller (1992). The precision was $\pm 5 \%$ with a detection limit of $0.1 \mu \mathrm{mol} \mathrm{L}-1 . \mathrm{NO}_{3}^{-}$and $\mathrm{NO}_{2}^{-}$, referred to as $\mathrm{NO}_{x}$, were analysed by the colorimetric method developed by Schnetger and Lehners (2014) and measured with a powerwave XS2 microplate spectrophotometer. The precision was $2 \%$, and the limit of detection was $0.4 \mu \mathrm{mol} \mathrm{L}^{-1}$. DIN was calculated as the sum of $\mathrm{NH}_{4}^{+}, \mathrm{NO}_{3}^{-}$and $\mathrm{NO}_{2}^{-}$. TDN was analysed in 2012 by hightemperature combustion (HTC) using a total organic carbon analyser (TOC-vpn, Shimadzu) with a TNM-1 module, and a precision of $2 \%$. DON was calculated as the difference between TDN and DIN (i.e. DON $=\mathrm{TDN}-\left[\mathrm{NH}_{4}^{+}+\mathrm{NO}_{x}\right]$ ). DON calculations were only possible in 2012 based on TDN measurements. The DON measurement is still problematic since it combines the analytical errors and uncertainties of the three analyses. Nevertheless, there is currently no single accepted method for the measurement of DON (Hansell and Carlson, 2014). Here we estimated the precision to be around $10 \%$. Dissolved iron was analysed using a 5100PC flame atomic absorption spectrophotometer (5100ZL Zeeman Furnace). Analytical uncertainties were $<5 \%$.

\section{Results}

\subsection{Distribution of salinity and oxygen saturation}

Previous studies have already discussed the distribution of physico-chemical parameters along the groundwater flow path at Martinique Beach based on 2012 and 2013 data (Chaillou et al., 2014, 2016; Couturier et al., 2016). Here, we will briefly present an overview of the salinity and redox conditions in the STE (Fig. 2).

In 2011 and 2012, the landward part of the STE was mostly characterized by suboxic freshwater (dissolved oxygen $([\mathrm{DO}])<20 \%$, salinity $<10)$. The discharge zone with the saline circulation cell was salty and oxygenated ([DO] $>60 \%$, salinity $>20$ ). A sharp salinity gradient occurred below the saline circulation cell, with salinity falling to 0 within the upper $50 \mathrm{~cm}$ of the sediment. In 2013 and 2015 , the focus on the intertidal zone confirmed the occurrence of a small saline circulation cell with sharp gradients of salinity and DO along its perimeter. Fresh and suboxic water were recurrent at $60 \mathrm{~cm}$ below the surface in the discharge zone of the beach. A mixing zone composed of brackish water (salinity comprised between 7 and 15) occurred along the perimeter of the saline circulation cell resulting from a mixture of fresh and saline groundwater. This mixing zone appeared to be depleted in DO $([\mathrm{DO}]<20 \%)$. The rest of the system was composed of fresh groundwater. In 2013, some measurements showing high DO concentrations in the deepest samples may indicate atmospheric contamination during sampling. 


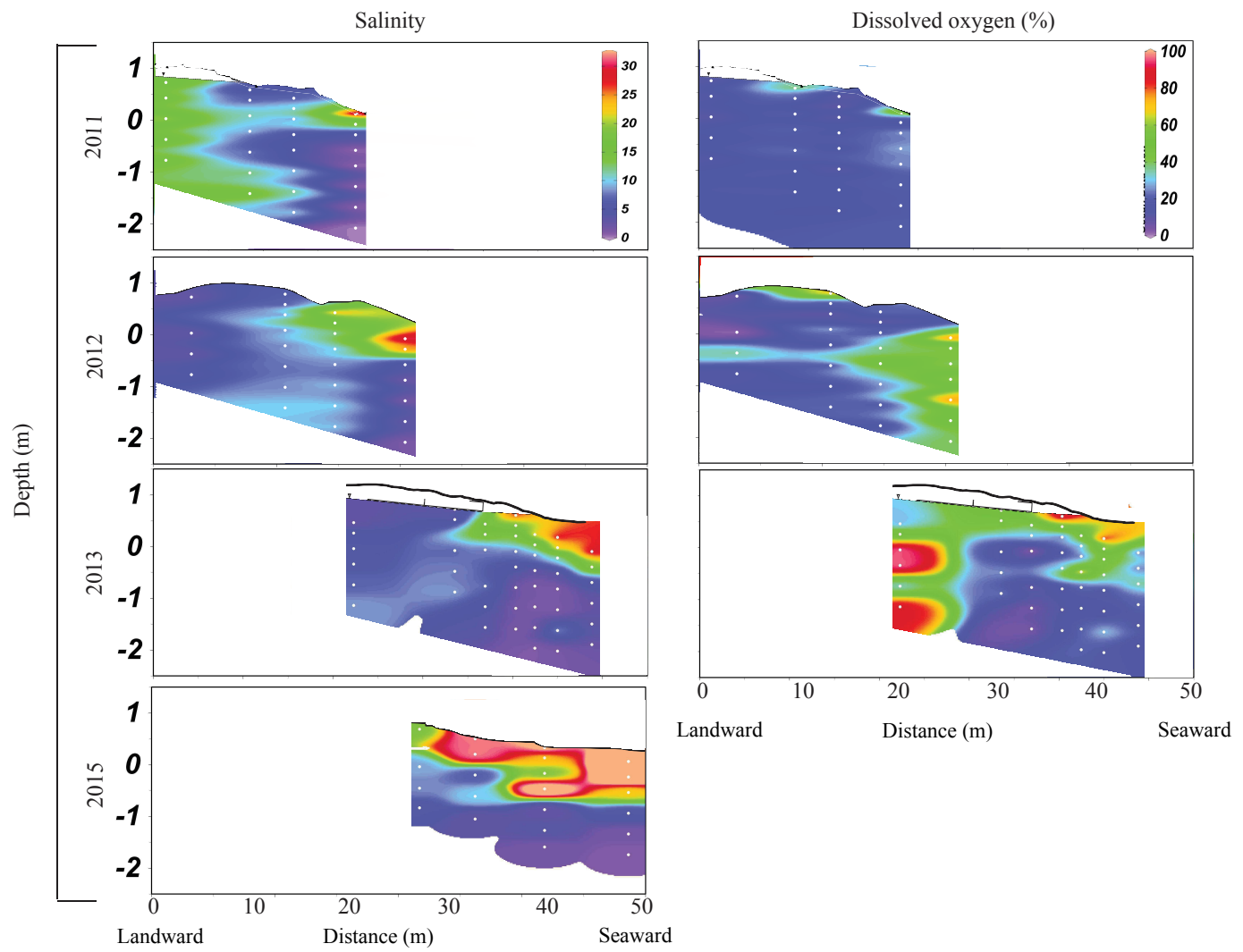

Figure 2. Cross-sections of the transect (see Fig. 1c) showing the beach profile and mean distribution of salinity and dissolved oxygen in 2011, 2012, 2013 and 2015 (no dissolved oxygen data are available for 2015). Depths are relative to mean sea level (i.e. $0 \mathrm{~m}$ is mean sea level). Contour lines were derived by spatial interpolation (kriging method) of data points; the interpolation model reproduced the empirical data set with a $97 \%$ confidence level. White dots represent the depths at which samples were collected using multi-level samplers. The dashed line represents the water table level.

Table 1. Mean concentrations $\left(\mu \mathrm{mol} \mathrm{L}{ }^{-1}\right)$ of nitrogen species in the groundwater and seawater endmembers as well as ranges in beach groundwater measured during the study. $\mathrm{NO}_{x}$ and $\mathrm{NH}_{4}^{+}$were measured in 2011, 2012, 2013 and 2015; TDN and DON were measured in 2012.

\begin{tabular}{lrrr}
\hline & Inland wells & Seawater & Beach groundwater \\
\hline $2011-2015$ & $\mathrm{~N}=10$ & $\mathrm{~N}=6$ & $\mathrm{~N}=245$ \\
$\mathrm{NO}_{x}$ & $65.5 \pm 26.7$ & $0.5 \pm 0.5$ & $0-26.1$ \\
$\mathrm{NH}_{4}^{+}$ & $0.1 \pm 0.3$ & $0.8 \pm 0.5$ & $0.1-1056.2$ \\
\hline 2012 & $\mathrm{~N}=2$ & $\mathrm{~N}=3$ & $\mathrm{~N}=54$ \\
$\mathrm{DON}$ & $110.9 \pm 3.4$ & $7.3 \pm 0.8$ & $0-1481.8$ \\
TDN & $203 \pm 4.5$ & $9.1 \pm 1.1$ & $7.4-1704.4$ \\
\hline
\end{tabular}

\subsection{Nutrient distribution from inland groundwater to beach groundwater}

The concentrations of $\mathrm{NO}_{x}\left(\Sigma \mathrm{NO}_{3}^{-}+\mathrm{NO}_{2}^{-}\right)$measured in four inland wells ranged from 14 to $94 \mu \mathrm{mol} \mathrm{L}^{-1}$ with a mean concentration of $65.5 \pm 26.7 \mu \mathrm{mol} \mathrm{L}^{-1}$ (Table 1). In the nearshore well, located $50 \mathrm{~m}$ from the shoreline, the concentration reached $20 \mu \mathrm{mol} \mathrm{L}-1 . \mathrm{NH}_{4}^{+}$concentrations were low, with concentrations varying between 0 and $1 \mu \mathrm{mol} \mathrm{L} \mathrm{L}^{-1}$. The fresh inland groundwater endmember was rich in TDN as measured in wells in 2012, with DON making up 53\% of the TDN (i.e. $\mathrm{DON}=110.9 \pm 3.4 \mu \mathrm{mol} \mathrm{L}{ }^{-1}$ ). Compared to fresh inland groundwater, the seawater samples were largely depleted in $\mathrm{NO}_{x}$ with a mean concentration of $0.5 \pm 0.5 \mu \mathrm{mol} \mathrm{L}^{-1}(\mathrm{~N}=6$, Table 1$) . \mathrm{NH}_{4}^{+}$concentrations were also low with $0.8 \pm 0.5 \mu \mathrm{mol} \mathrm{L} \mathrm{L}^{-1}$. As in fresh inland groundwater, TDN in seawater was largely dominated by DON that represented $\sim 80 \%$ of the $\mathrm{N}$ budget with a mean concentration of $7.3 \pm 0.8 \mu \mathrm{mol} \mathrm{L}{ }^{-1}$. Overall, TDN concentrations in the seawater endmember were 20 times lower than in the groundwater endmember.

Within the STE, $\mathrm{NO}_{x}$ concentrations were low (0$26 \mu \mathrm{mol} \mathrm{L}{ }^{-1}$ with a mean concentration of $1.9 \mu \mathrm{mol} \mathrm{L}^{-1}$ ). These concentrations were 5 times lower than those measured within the fresh groundwater endmember (Table 1, Fig. 3a). However, some samples collected in the deep and fresh part of the STE reached concentrations greater than 
(a) - NOx- $\mu \mathrm{M}$

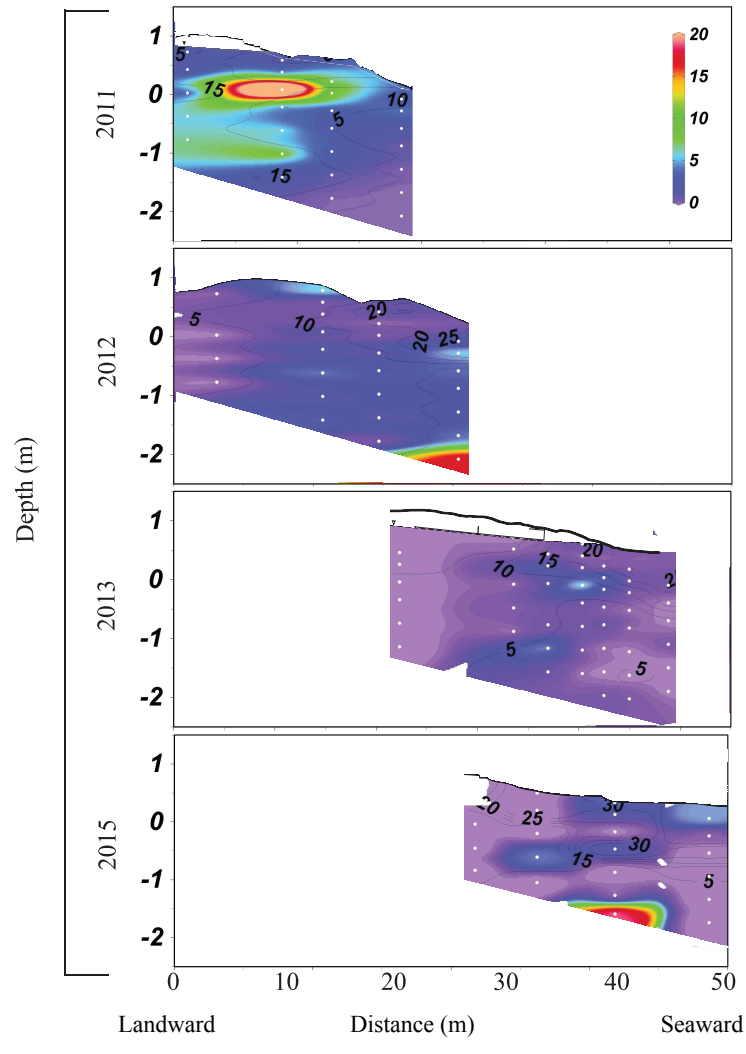

(b) $-\mathrm{NH}_{4}^{+}-\mu \mathrm{M}$

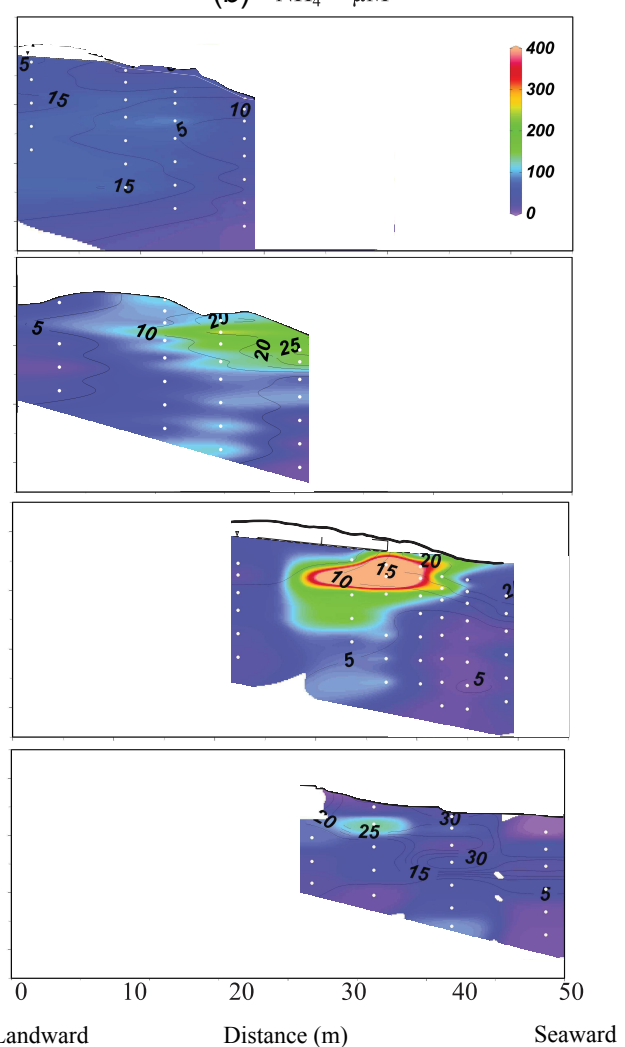

Figure 3. Cross-sections of the transect (see Fig. 1c) showing the beach profile and distributions of (a) nitrate + nitrite $\left(\mathrm{NO}_{x}\right)$ and (b) ammonium in $\mu \mathrm{mol} \mathrm{L}^{-1}$ in 2011, 2012, 2013 and 2015. Black contour lines refer to salinity. Depths are relative to mean sea level (i.e. $0 \mathrm{~m}$ is mean sea level). All contour lines were derived by spatial interpolation (kriging method) of data points. White dots represent the depths at which samples were collected using multi-level samplers.

$20 \mu \mathrm{mol} \mathrm{L}^{-1}$ (Fig. 3a). Such hot spots of $\mathrm{NO}_{x}$ concentrations were also recorded in 2011 (up to $15.2 \mu \mathrm{mol} \mathrm{L}^{-1}$ ), 2012 (up to $26.1 \mu \mathrm{mol} \mathrm{L}^{-1}$ ) and 2015 (up to $19.5 \mu \mathrm{mol} \mathrm{L}{ }^{-1}$ ). In contrast to $\mathrm{NO}_{x}, \mathrm{NH}_{4}^{+}$concentrations were high in the STE, with concentrations ranging from $\sim 20 \mu \mathrm{mol} \mathrm{L}^{-1}$ to $>500 \mu \mathrm{mol} \mathrm{L}^{-1}$ (Fig. 3b), and up to $1056 \mu \mathrm{mol} \mathrm{L}^{-1}$ (2013, Fig. 3b). Ammonium $\left(\mathrm{NH}_{4}^{+}\right)$concentrations measured in the STE were 1 to 1000 times higher than endmember values (Table 1, Fig. 3b). In 2013, an area of high concentrations was observed in the mixing zone, in front of the saline circulation cell, where $\mathrm{NH}_{4}^{+}$concentrations reached values greater than $400 \mu \mathrm{mol} \mathrm{L}^{-1}$ (Fig. 3b). $\mathrm{NH}_{4}^{+}$concentrations were still high in the saline circulation cell (e.g. 84-92 $\mu \mathrm{mol} \mathrm{L}^{-1}$ ), and these were also high compared to the overlying seawater endmember (Table 1). $\mathrm{NH}_{4}^{+}$concentrations decreased sharply with depth in the mixing zone. For example, in June 2013 maximum $\mathrm{NH}_{4}^{+}$concentrations were around $400 \mu \mathrm{mol} \mathrm{L}^{-1}$ at $30 \mathrm{~cm}$ below the beach surface of the intertidal zone and decreased to $50 \mu \mathrm{mol} \mathrm{L}{ }^{-1}$ at $230 \mathrm{~cm}$ (Fig. 3b). $\mathrm{NH}_{4}^{+}$was the main TDN species in the STE (on average $\mathrm{NH}_{4}^{+}$concentrations accounted for $60 \%$ of TDN in all samples). Thus, in 2012, the TDN distribution was quite similar to the $\mathrm{NH}_{4}^{+}$ distribution (Fig. 4), with high values in the mixing zone. TDN decreased sharply below the saline circulation cell and the mixing zone; values ranged from 50 to $100 \mu \mathrm{mol} \mathrm{L}^{-1}$ and dropped below detection below the saline circulation cell. DON represented $31 \%$ of the TDN in beach groundwater, and the highest concentrations were observed in the mixing zone (>200 $\mu \mathrm{mol} \mathrm{L}^{-1}$, Fig. 4). DON levels decreased below the saline circulation cell, with concentrations close to 0 .

$\mathrm{N}$ species showed different distributions relative to groundwater salinity and DO saturation along the STE (Fig. 5). $\mathrm{N}$ species were characterized by non-conservative behaviour relative to the theoretical two-endmember mixing between seawater and fresh inland groundwater. $\mathrm{NO}_{x}$ declined from $60 \mu \mathrm{mol} \mathrm{L}^{-1}$ in fresh inland groundwater to concentrations below detection in brackish and saline groundwater (Fig. 5a). The highest concentrations of $\mathrm{NO}_{x}$ were encountered when DO saturation was below $60 \%$. While dissolved $\mathrm{NO}_{x}$ showed removal in the flow path, $\mathrm{NH}_{4}^{+}$exhibited excess concentrations relative to conservative mixing between the two endmembers (Fig. $5 b$ ). $\mathrm{NH}_{4}^{+}$concentrations clearly showed strong production along the salinity gradient of the STE. The highest concentrations of $\mathrm{NH}_{4}^{+}$oc- 


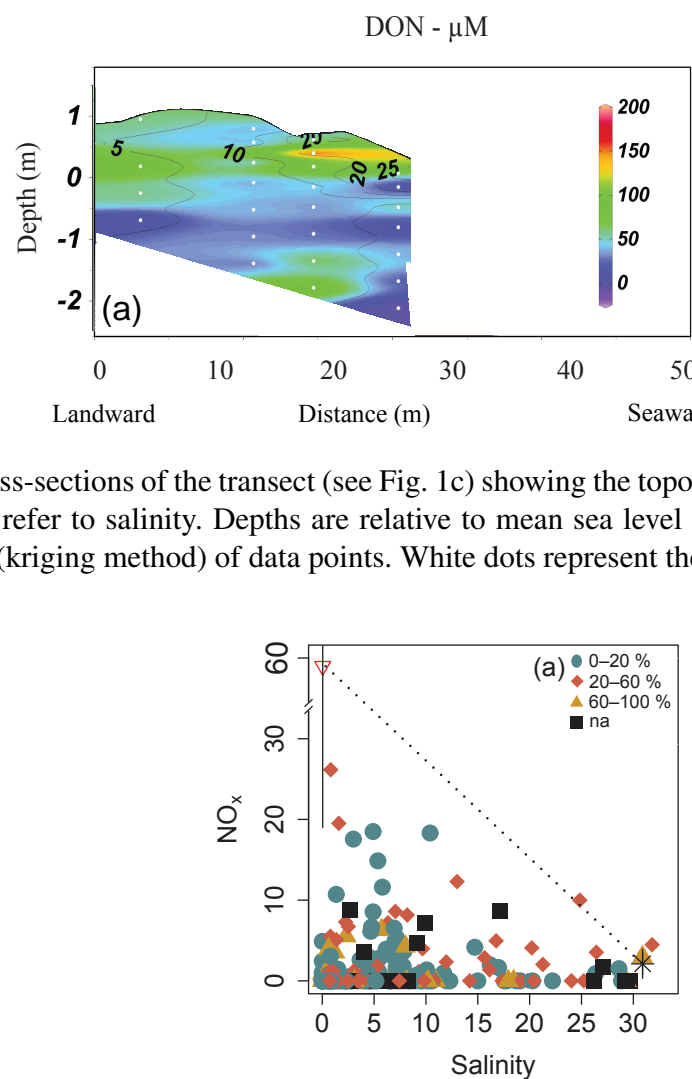

TDN $-\mu \mathrm{M}$

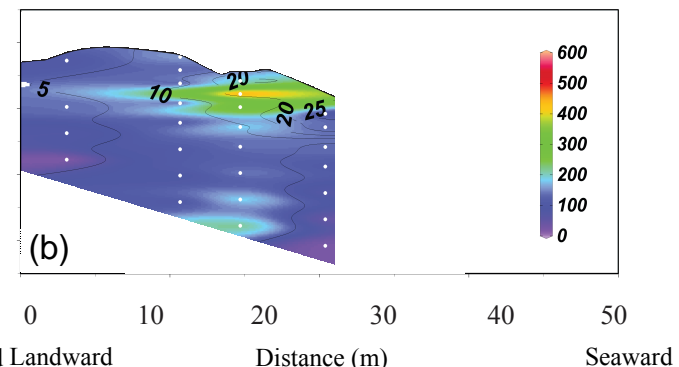

Figure 4. Cross-sections of the transect (see Fig. 1c) showing the topography and distributions of DON and TDN in $\mu \mathrm{mol} \mathrm{L}^{-1}$ in 2012 . Black contour lines refer to salinity. Depths are relative to mean sea level (i.e. $0 \mathrm{~m}$ is mean sea level). All contour lines were derived by spatial interpolation (kriging method) of data points. White dots represent the depths at which samples were collected using multi-level samplers.
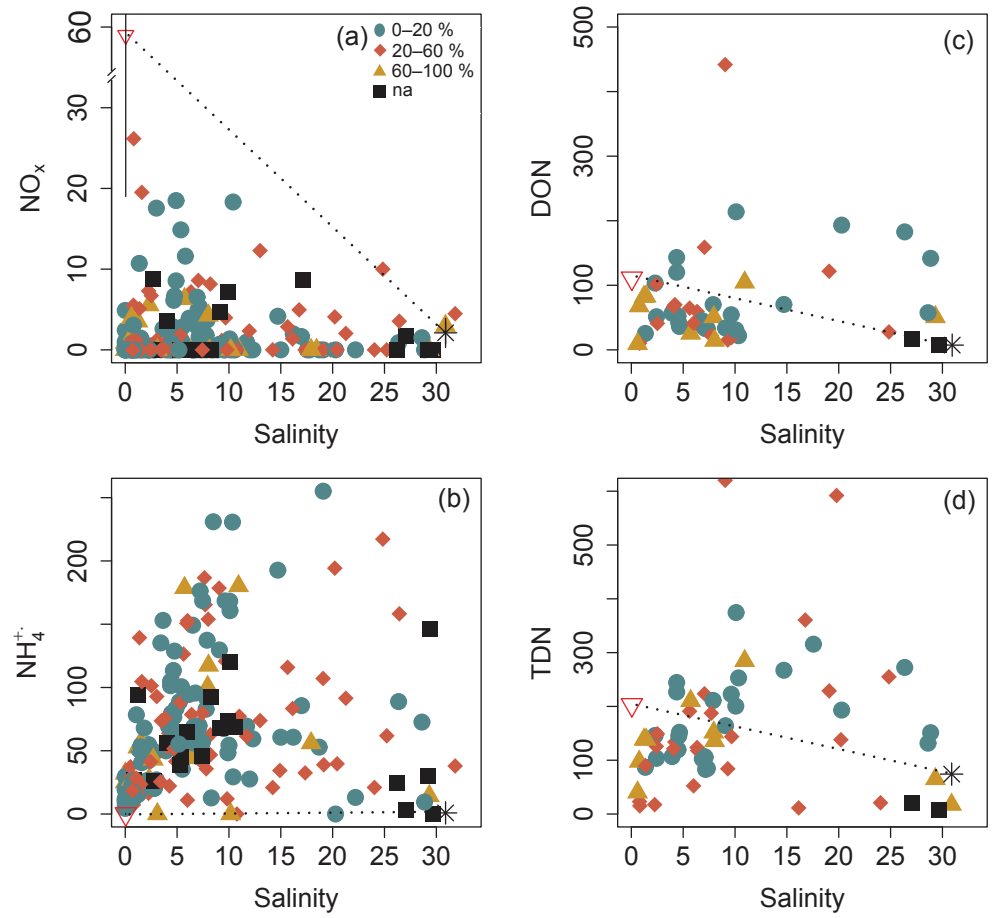

Figure 5. Distribution of $\mathrm{NO}_{x}$ and $\mathrm{NH}_{4}^{+}$groundwater concentration in $\mu \mathrm{mol} \mathrm{L}{ }^{-1}$ collected in 2011, 2012, 2013 and 2015 (a, b) and DON and TDN in 2012 (c, d) within the STE relative to salinity grouped for different DO saturation from 0 to 20,20 to 60 and 60 to $100 \%$. Extra points are not included to allow for better visibility. Black dots were used when no data on DO saturation were available. Red triangles are mean groundwater endmember values, and black squares are mean seawater endmember values. Standard deviations are black lines associated with endmembers. Dashed lines represent the theoretical mixing line between groundwater and seawater endmembers.

curred mainly under suboxic conditions $([\mathrm{DO}]<20 \%)$ and decreased significantly with increased DO ( $p$ value $<0.05)$. Both $\mathrm{NH}_{4}^{+}$and $\mathrm{NO}_{x}$ were observed in 81 of 245 samples ( $\sim 33 \%$ of the data set). These samples were mainly located just below the saline circulation cell and the associated mixing zone, where oxygen-depleted conditions prevailed $([\mathrm{DO}]<20 \%)$. In contrast to the behaviour of $\mathrm{NO}_{x}$ and $\mathrm{NH}_{4}^{+}$, TDN and DON exhibited a distinct trend along the salinity gradient: (i) they fell below the theoretical mixing line in fresh and brackish waters (salinity 0-10), and this removal occurred in suboxic-anoxic conditions, and (ii) their concentrations increased above the theoretical mixing line in saline waters (salinity $>10$ ). There was no significant relationship with DO.

Total dissolved iron concentrations were high in the STE and ranged from 1 to $2700 \mu \mathrm{mol} \mathrm{L}{ }^{-1}$ with a mean concen- 


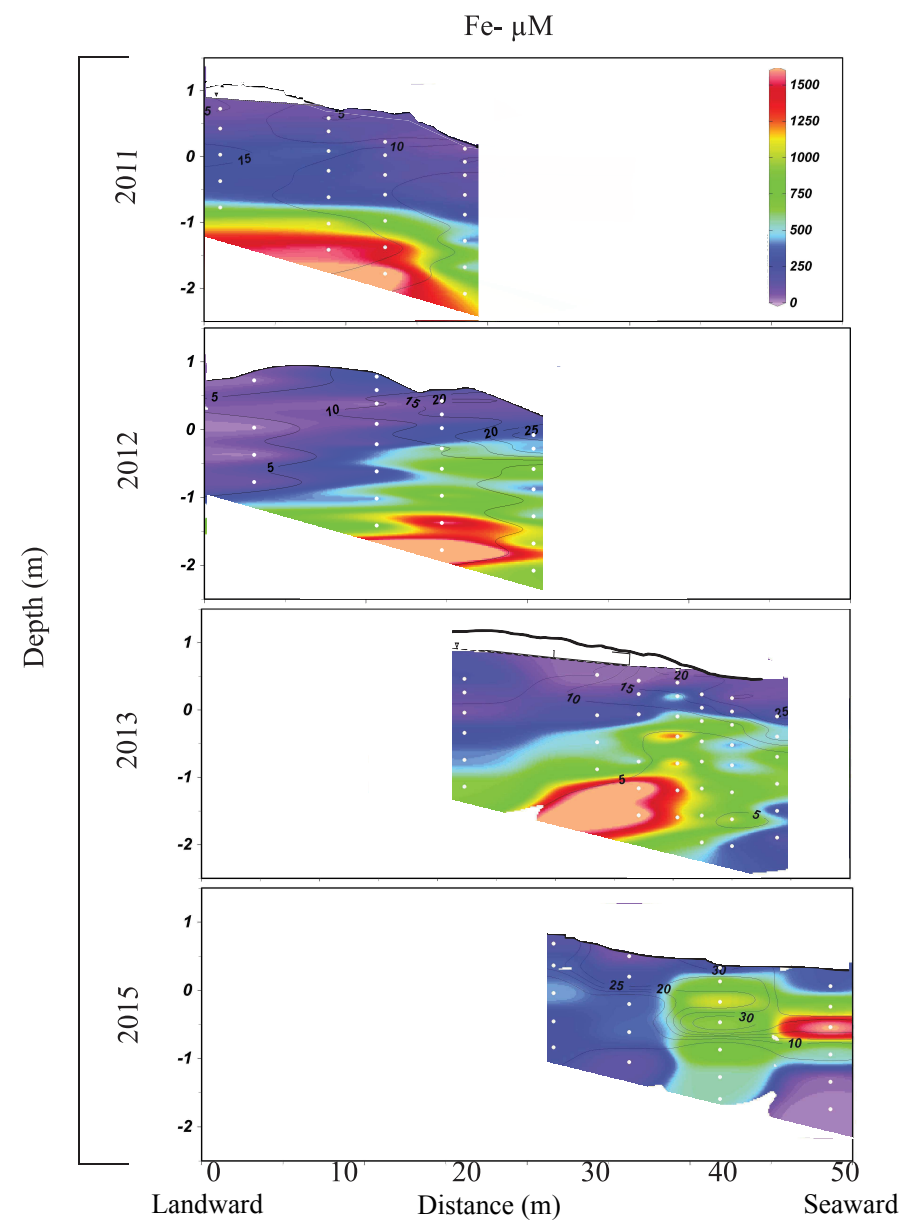

Figure 6. Cross-sections of the transect (see Fig. 1c) showing the topography and distributions of dissolved iron in $\mu \mathrm{mol} \mathrm{L}^{-1}$ in 2011,2012 , 2013 and 2015. White contour lines refer to salinity. Depths are relative to mean sea level (i.e. $0 \mathrm{~m}$ is mean sea level). All contour lines were derived by spatial interpolation (kriging method) of data points. White dots represent the depths at which samples were collected using multi-level samplers.

tration of $520 \mu \mathrm{mol} \mathrm{L}{ }^{-1}$ (Fig. 6). Concentrations increased sharply with depth and below the saline circulation cell. Concentrations of dissolved iron in the upper metre of the STE and in the saline circulation cell were lower, but still high (from 1 to $100 \mu \mathrm{mol} \mathrm{L}^{-1}$ ) compared to the overlaying water.

\section{Discussion}

\subsection{Biogeochemical controls of DIN concentrations along the groundwater flow path}

The non-conservative behaviour of DIN along the groundwater flow path influences the nutrient concentration in discharging groundwater, while at the same time making it difficult to estimate the flux of groundwater-derived DIN to the coastal ocean (Johannes, 1980; Moore, 2010; Valiela et al., 1990). The calculation of chemical fluxes using samples from inland wells may result in significant errors in estimated chemical fluxes. Processes occurring in the STE must be elucidated to improve our understanding of the role of the STE in altering groundwater-derived N. The DIN pool changed from $\mathrm{NO}_{x}$-rich groundwater in the aquifer to $\mathrm{NH}_{4}^{+}$rich groundwater in the STE. In our study, $\mathrm{NO}_{x}$ represented $99 \%$ of the DIN pool in the fresh inland groundwater endmember but only $37 \%$ in the seawater endmember. In the next section, the potential biogeochemical mechanisms controlling the $\mathrm{N}$ pool along the flow path are explored.

\subsubsection{Nitrate loss along the STE}

$\mathrm{NO}_{x}$ concentrations were low within the STE in contrast to the high concentrations measured in fresh inland groundwater. There was strong attenuation in $\mathrm{NO}_{x}$, with mean concentrations of $60 \mu \mathrm{mol} \mathrm{L}^{-1}$ in inland wells $(\sim 500$ to $1500 \mathrm{~m}$ from the shoreline), dropping to $\sim 20 \mu \mathrm{mol} \mathrm{L}^{-1}$ in the nearshore well $(50 \mathrm{~m}$ from the shoreline) and to $2 \mu \mathrm{mol} \mathrm{L}^{-1}$ in the STE, near the discharge zone. Such attenuation of $\mathrm{NO}_{x}$ is common in groundwater (Rivett et al., 
2008), and denitrification is generally recognized as the most significant mass removal process along the flow path (Korom, 1992). Denitrification is central to the nitrogen cycle in the subsurface groundwater environment. It involves the reduction of $\mathrm{NO}_{x}$ to $\mathrm{N}_{2}$ gas via a chain of microbial reduction reactions.

As oxygen-depleted conditions and high dissolved organic carbon (DOC) concentrations are encountered along the STE (Couturier et al., 2016), denitrification may be one of the processes driving rapid groundwater-borne $\mathrm{NO}_{x}$ loss. The stoichiometry of nitrate reduction and the oxidation of organic matter by denitrification, given by Jørgensen et al. (2014), are as follows:

$5 \mathrm{CH}_{2} \mathrm{O}+4 \mathrm{NO}_{3}^{-}+4 \mathrm{H}^{+}=2 \mathrm{~N}_{2}+5 \mathrm{CO}_{2}+7 \mathrm{H}_{2} \mathrm{O}$.

According to this stoichiometry, the mean concentration of DOC observed in the STE (i.e. $1940 \mu \mathrm{mol} \mathrm{C} \mathrm{L}^{-1}$; Couturier et al., 2016) could be used to reduce $1550 \mu \mathrm{mol} \mathrm{L}^{-1}$ of nitrate to dinitrogen by denitrification. With concentrations of $\mathrm{NO}_{x}$ around $20 \mu \mathrm{mol} \mathrm{L}^{-1}$ in the nearshore well, this means that all groundwater-borne $\mathrm{NO}_{3}^{-}$may conceivably be reduced by DOC. However, even if the concentration of DOC in groundwater is high, Couturier et al. (2016) showed that dissolved organic matter (DOM) had a strong terrestrial signature along the STE at Martinique Beach. This OC was characterized by a high-molecular-weight and was enriched in lignin-derived compounds. In an alluvial aquifer, Baker and Vervier (2004) confirmed that the rate of denitrification was best predicted by the concentration of low-molecular-weight organic acids compared to high-molecular-weight compounds. In an unconfined sandy aquifer, Postma et al. (1991) reported that nitrate reduction was minimal when $\mathrm{OC}$ was present as lignin and lignite fragments (i.e. as high-molecular-weight compounds). Thus, the terrestrial DOC present in the Martinique Beach STE may not promote high rates of heterotrophic denitrification at the study site.

Nitrate reduction can be supported, however, by electron donors other than organic matter such as $\mathrm{Fe}^{2+}$ (Aller, 1994; Postma, 1990). There is evidence that groundwater containing $\mathrm{Fe}^{2+}$ contains little or no nitrate (Korom, 1992). The presence of reduced iron is assumed to facilitate the occurrence of denitrification according to Reactions 2 and 3:

$$
\begin{aligned}
& 5 \mathrm{Fe}^{2+}+\mathrm{NO}_{3}^{-}+12 \mathrm{H}_{2} \mathrm{O}=\mathrm{Fe}(\mathrm{OH})_{3}+\frac{1}{2} \mathrm{~N}_{2}+9 \mathrm{H}^{+}, \\
& 10 \mathrm{Fe}^{2+}+2 \mathrm{NO}_{3}^{-}+14 \mathrm{H}_{2} \mathrm{O}=10 \mathrm{FeOOH}+\mathrm{N}_{2}+18 \mathrm{H}^{+}
\end{aligned}
$$

High DOC concentrations (Couturier et al., 2016) support the reductive dissolution of $\mathrm{Fe}$ oxyhydroxides and lead to total dissolved iron concentrations as high as 1000 $1600 \mu \mathrm{mol} \mathrm{L}{ }^{-1}$, with concentrations reaching $2700 \mu \mathrm{mol} \mathrm{L}-1$ in deep groundwater below the saline circulation cell (Fig. 6). Thus $\mathrm{Fe}^{2+}$ can act as an electron donor and may have induced a loss of nitrates along the flow path. This autotrophic denitrification is most efficient in aquifers with low nitrate input
(Postma et al., 1991) and in margin sediments (Anschutz et al., 2002; Chaillou et al., 2007; Hulth et al., 1999; Hyacinthe et al., 2001). The stoichiometry of Reactions 2 and 3 shows that $1 \mathrm{~mol} \mathrm{Fe}^{2+}$ can reduce $0.2 \mathrm{~mol} \mathrm{NO}_{3}^{-}$. Based on the range of $\mathrm{Fe}^{2+}$ concentrations measured along the transect, this process is capable of completely reducing groundwater-borne $\mathrm{NO}_{x}$.

With a maximum groundwater flow rate of $0.029 \mathrm{~m}^{3} \mathrm{~s}^{-1}$ in beach groundwater (Chaillou et al., 2016), the groundwater transit time through the STE $(\sim 50 \mathrm{~m})$ is about 166 days, which is long enough to support denitrification reactions and subsequent $\mathrm{N}$ transformations. Hot spots of $\mathrm{NO}_{x}$ concentrations (e.g. $7.5 \mu \mathrm{mol} \mathrm{L}^{-1}$ at $50 \mathrm{~cm}$ depth with $[\mathrm{DO}]<10 \%$ in $2013,15.2 \mu \mathrm{mol} \mathrm{L}^{-1}$ at $80 \mathrm{~cm}$ depth with [DO] $<30 \%$ in 2012 and 2015; Fig. 3a) were likely the result of local and sporadic production rather than traces of groundwater-borne $\mathrm{NO}_{x}$. The downward infiltration of oxygenated seawater by tides could be large enough to oxidize $\mathrm{NH}_{4}^{+}$and produce $\mathrm{NO}_{3}^{-}$along the saline circulation cell. These concentrations of $\mathrm{NO}_{3}^{-}$remained low $\left(<6 \mu \mathrm{mol} \mathrm{L}{ }^{-1}\right)$ in the STE probably because of the multiple electron donors that can be used to reduce $\mathrm{NO}_{3}^{-}$to $\mathrm{N}_{2}$ under anoxic conditions (i.e. $\mathrm{DOC}, \mathrm{Fe}^{2+}$, $\mathrm{NH}_{4}^{+}, \mathrm{H}_{2} \mathrm{~S}$ and $\mathrm{FeS}$ ).

\subsubsection{Ammonium production along the STE}

Mineralization of organic matter is likely the most important source of $\mathrm{NH}_{4}^{+}$in the Martinique Beach STE. DON measurements in 2012 were high $\left(0-1481 \mu \mathrm{mol} \mathrm{L}^{-1}\right)$, with a mean value of $80 \mu \mathrm{mol} \mathrm{L}^{-1}$. DON is a complex mixture of primarily uncharacterized compounds, of which 10 to $70 \%$ are estimated to be bioavailable (Seitzinger et al., 2002). DON bioavailability is often reported to be dependent on the nature of compounds (Sipler and Bronk, 2014). In the beach groundwater, DON represented $39 \%$ of the TDN, so its mineralization by heterotrophic microorganisms could be responsible for part of the $\mathrm{NH}_{4}^{+}$production in the STE (Kroeger et al., 2006). Ammonium production is mainly located upstream of the saline circulation cell (Fig. 3b) and is linked to the presence of high DON concentrations as observed in June 2012 (Fig. 4). Because ammonification is highly dependent on the bioavailability of DON, it is difficult to estimate what fraction of $\mathrm{NH}_{4}^{+}$could be derived from DON mineralization. Based on the estimate that 10 to $70 \%$ of DON is bioavailable as proposed by Seitzinger et al. (2002), mineralization of DON could lead to the production of 8 to $56 \mu \mathrm{mol} \mathrm{L}^{-1}$ of $\mathrm{NH}_{4}^{+}$, which represents between 2 and $10 \%$ of the $\mathrm{NH}_{4}^{+}$concentration observed in beach groundwater.

In coastal sediments, where sulfate is not limiting, sulfate reduction produces $\mathrm{NH}_{4}^{+}$according to the following reaction:

$$
\begin{aligned}
& 53 \mathrm{SO}_{4}^{2-}+\left(\mathrm{CH}_{2} \mathrm{O}\right)_{106}\left(\mathrm{NH}_{3}\right)_{16}\left(\mathrm{H}_{3} \mathrm{PO}_{4}\right)=39 \mathrm{CO}_{2} \\
& +67 \mathrm{HCO}_{3}^{-}+16 \mathrm{NH}_{4}^{+}+53 \mathrm{HS}^{-}+39 \mathrm{H}_{2} \mathrm{O}+\mathrm{HPO}_{4}^{2-}
\end{aligned}
$$




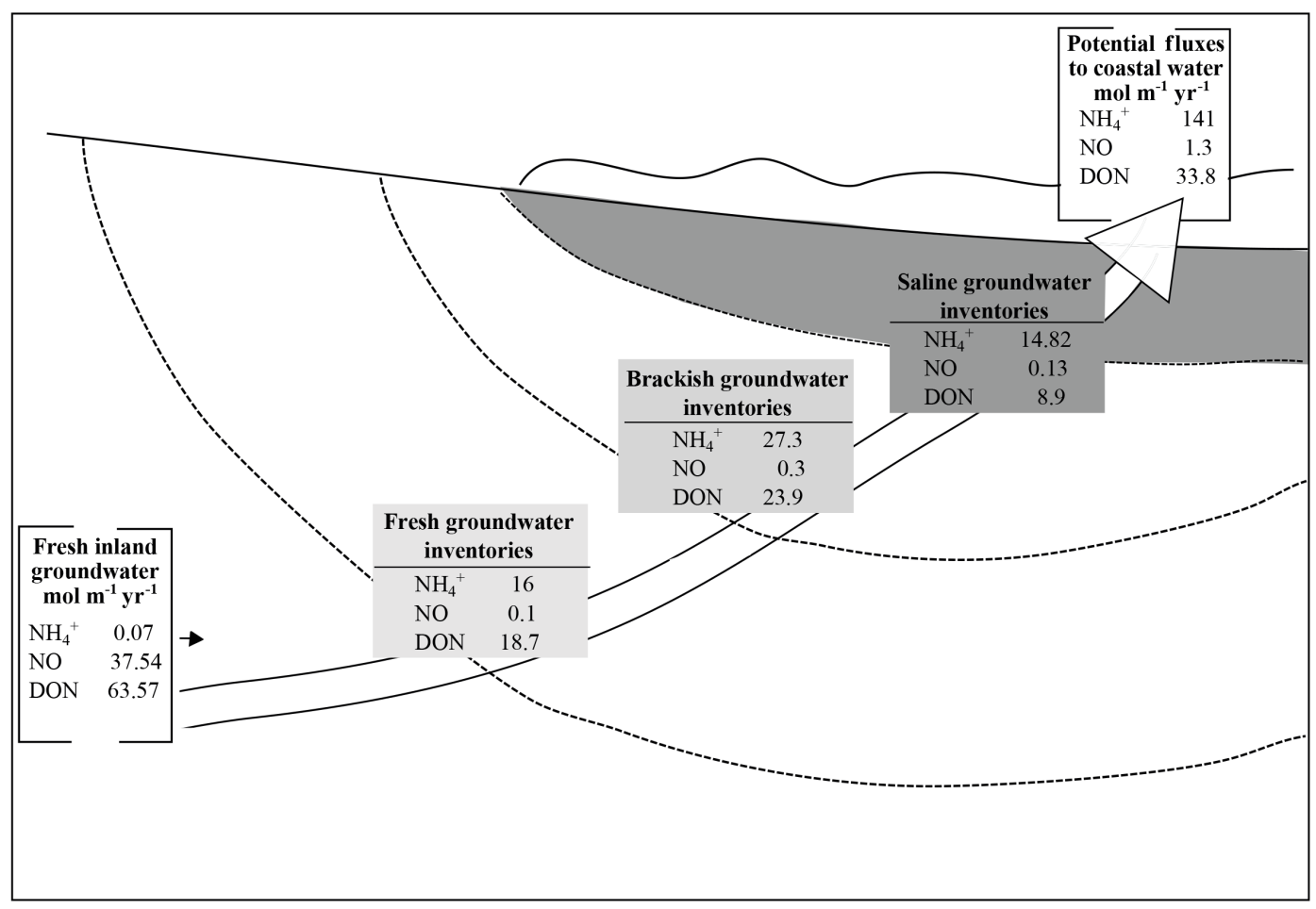

Figure 7. Schematic representation of (1) $\mathrm{N}$ inventories in fresh, brackish and saline beach groundwater (boxes from light grey to dark grey; dashed lines represent the schematic salinity separation) and of (2) fresh inland groundwater fluxes and potential exported fluxes to coastal water (white boxes). White arrow schematizes the groundwater flow path from the inland groundwater to the seepage face. The increase in TDN along the groundwater flow path is attributed to release of $\mathrm{N}$ from particulate organic matter of terrestrial origin.

$\mathrm{NH}_{4}^{+}$was observed in samples with salinity $>4$, with the highest concentrations $\left(\sim 1.25 \mathrm{mmol} \mathrm{L}^{-1}\right)$ at salinity around 15. At salinity 15 , we estimate a $\mathrm{SO}_{4}^{2-}$ concentration of $12 \mathrm{mmol} \mathrm{L}^{-1}$ in beach surface groundwater, which is sufficient to produce $3.6 \mathrm{mmol} \mathrm{L}^{-1} \mathrm{NH}_{4}^{+}$by sulfate reduction. This reaction could therefore explain the remainder of $\mathrm{NH}_{4}^{+}$ production in beach groundwater.

The breakdown of macro-algal deposits derived from wave and tidal action in sediments can also increase $\mathrm{N}$ input to beach groundwater (Kelaher and Levinton, 2003; Rossi et al., 2011) and can potentially add $\mathrm{NH}_{4}^{+}$. At Martinique Beach, algal deposits were not specifically measured but were often observed after storm events. In addition, external contamination from wastewater or sceptic tank seepages cannot be completely excluded. Nevertheless, the absence of traces of $\mathrm{NH}_{4}^{+}$contamination in the landward part of the beach and the stable isotopes of water reported by Chaillou et al. (2017) do not support an anthropogenic $\mathrm{NH}_{4}^{+}$input.

\subsection{Nutrient transport along the flow path}

The non-conservative behaviour of nutrients within the STE makes it difficult to estimate the export of nutrients to the coastal ocean. As pointed out in the review by Moore (2010), robust measurements of nutrient fluxes are needed on a site- specific scale to obtain accurate regional and global estimates. In non-conservative systems, however, the determination of appropriate nutrient endmember concentrations for flux calculations is not straightforward. Beck et al. (2007) previously highlighted the need to closely scrutinize the biogeochemical processes in the STE to refine nutrient export fluxes to coastal areas. Here, inorganic and organic $\mathrm{N}$ inventories were estimated along the groundwater flow path based on salinity. Then the potential nitrogen fluxes out of the STE were estimated and compared to the fresh inland groundwater-borne nutrient fluxes. Fluxes and inventories of the different $\mathrm{N}$ species along the groundwater flow path are summarized in Fig. 7.

\subsubsection{Nitrogen inventories}

Nutrient inventories were calculated by integrating nutrient concentrations at sampling locations according to salinity and multiplying by the sediment porosity (i.e. 0.25 ; Chaillou et al., 2012). Salinity was used to delimit zones to calculate $\mathrm{N}$ inventories along the flow path in deep fresh groundwater with low salinity $(S<5 ; \mathrm{N}=57)$; in the brackish beach groundwater $(5<S<15 ; \mathrm{N}=19)$ that runs parallel to the surficial saline circulation cell; and, finally, in saline groundwa- 
Table 2. Nutrient inventories estimated along the STE. Inventories were calculated in fresh, brackish and saline beach groundwater; the 2013 data set was used. For dissolved organic nitrogen, concentrations measured in 2012 were used.

\begin{tabular}{lrrrrrr}
\hline & $\mathrm{N}$ & \multicolumn{5}{c}{ Inventories $\left[\mu \mathrm{mol} \mathrm{m}{ }^{-2}\right]$} \\
\hline Beach groundwater & & $\mathrm{NH}_{4}^{+}$ & $\mathrm{NO}_{3}^{-}$ & $\mathrm{DIN}$ & $\mathrm{DON}^{\mathrm{a}}$ & $\mathrm{TDN}^{\mathrm{a}}$ \\
\hline Freshwater $(S<5)$ & 57 & 16 & 0.1 & 16.1 & 18.7 & 34.8 \\
Brackish water $(5<S<15)$ & 19 & 27.3 & 0.3 & 27.6 & 23.9 & 51.5 \\
Saline water $(S>15)$ & 15 & 14.8 & 0.1 & 15 & 8.9 & 24 \\
\hline
\end{tabular}

${ }^{a}$ Calculated on 2012 sampling.

ter $(S>15 ; \mathrm{N}=15)$. Inorganic and organic nitrogen inventories are presented in Table 2.

In the inland groundwater wells, fresh groundwater was rich in DON (Table 1). DIN represented only $33 \%$ of the TDN, with $\mathrm{NO}_{x}$ making up $95 \%$ of the inorganic pool (Table 1). In the fresh beach groundwater $(S<5)$, nutrient inventories showed that DON was still the main $\mathrm{N}$ species with an inventory of $18.7 \mu \mathrm{mol} \mathrm{m}^{-2}$ (Table 2), which represented more than $50 \%$ of the TDN pool. In DIN, a shift from $\mathrm{NO}_{x}$ to $\mathrm{NH}_{4}^{+}$occurred from the inland groundwater to deep fresh beach groundwater: $\mathrm{NO}_{x}$ became a negligible fraction $\left(\mathrm{NO}_{x}\right.$ inventory $<0.5 \mu \mathrm{mol} \mathrm{m}{ }^{-2}$ ), whereas $\mathrm{NH}_{4}^{+}$was the main inorganic fraction, representing 46, 53 and $61 \%$ of the TDN in fresh, brackish and saline beach groundwater respectively.

$\mathrm{NH}_{4}^{+}$was clearly produced along the groundwater flow path through the STE. In brackish groundwater, a strong production of TDN was observed: DIN, $\mathrm{NH}_{4}^{+}$and DON increased by 169, 168 and $127 \%$ respectively (Fig. 7). Based on the previous work of Couturier et al. (2016), the source of nitrogen released in the STE is thought to be mineralization of terrestrial rather than marine organic matter. This strong in situ TDN production in the brackish beach groundwater altered the groundwater-borne $\mathrm{N}$ pool. Indeed, TDN concentrations in the saline circulation cell are much higher than the input from inland groundwater, even if this TDN is subsequently attenuated in surface sediment in the saline circulation cell due to biogeochemical processes and dilution (Table 2). Our findings showed that, even if groundwater-borne TDN in the form of $\mathrm{NO}_{3}^{-}$and $\mathrm{DON}$ was mostly attenuated along the groundwater flow path, a "new" N pool was produced within the STE as it was already observed for DOM (Couturier et al., 2016).

\subsubsection{Nitrogen fluxes}

The fresh groundwater-borne $\mathrm{N}$ fluxes to the STE have been calculated as the product of the mean DON, $\mathrm{NO}_{x}$ and $\mathrm{NH}_{4}^{+}$ concentrations of the fresh inland groundwater endmember and the flow of fresh groundwater on shore (Chaillou et al., 2016). The fresh inland groundwater-derived $\mathrm{N}$ input estimated in this way was $<0.07$ and $37 \mathrm{~mol} \mathrm{~m}^{-1} \mathrm{yr}^{-1}$ for $\mathrm{NH}_{4}^{+}$and $\mathrm{NO}_{x}$ respectively. Estimated DIN and DON fluxes are $37 \mathrm{~mol} \mathrm{~m}^{-1} \mathrm{yr}^{-1}$ and $63 \mathrm{~mol} \mathrm{~m}^{-1} \mathrm{y}^{-1}$ respectively (Ta-
Table 3. $\mathrm{N}$ fluxes delivered to STE and exported to coastal ocean in $\mathrm{mol} \mathrm{m}^{-1} \mathrm{yr}^{1}$. Fresh inland groundwater-borne fluxes were computed as the product of average concentrations of $\mathrm{N}$ in groundwater endmembers and the volume of fresh groundwater discharge ( $\left.Q_{\text {inland }}\right)$. The exported $\mathrm{N}$ fluxes were the product of $\mathrm{N}$ inventory at the high-tide mark and the flow measured in the beach ( $\left.Q_{\text {beach }}\right)$. Inorganic N fluxes were estimated based on 2013 sampling, and DON fluxes were based on 2012 sampling.

\begin{tabular}{lrrrr}
\hline Fluxes mol m & $\mathrm{NH}_{4}^{+1} \mathrm{yr}^{-1}$ & $\mathrm{NO}_{x}$ & $\mathrm{DIN}$ & $\mathrm{DON}^{\mathrm{a}}$ \\
\hline Fresh inland groundwater & 0.07 & 37 & 37 & 63 \\
Exported N & 141 & 1.3 & 142.3 & 33.8 \\
\hline
\end{tabular}

${ }^{\text {a }}$ Calculated based on 2012 sampling with hydrologic flow determined in 2013.

ble 3). The estimated groundwater-borne TDN flux was approximately $102 \mathrm{~mol} \mathrm{~m}^{-1} \mathrm{yr}^{-1}$, corresponding to an annual $\mathrm{N}$ input of $\sim 1700 \mathrm{~kg}$ along the $1200 \mathrm{~m}$ Martinique Beach shoreline. This flux is dominated by DON and $\mathrm{NO}_{x}$. Inland groundwater clearly acts as a source of nitrogen to the beach groundwater, as has been observed in other STEs, such as in Dor Bay (Mediterranean coast; Weinstein et al., 2011), Cockburn Sound (western Australia; Loveless and Oldham, 2010) and Waquoit Bay (Cape Cod, MA; Talbot et al., 2003; Gonneea and Charette, 2014). However, the groundwaterborne $\mathrm{N}$ load at Martinique Beach was very low in comparison to the above-mentioned sites, where fresh groundwater $\mathrm{NO}_{x}$ concentrations as high as $300 \mu \mathrm{mol} \mathrm{L}^{-1}$ were reported.

Estimates of nutrient export from the STE to the coastal ocean are more difficult to obtain. Direct measurements (from surface sediment incubations) are probably the most accurate ways to measure export. However, the spatial patchiness of seeps at the discharge zone and the effect of tides on the hydraulic gradient in the beach aquifer lead to significant variability in direct measurements of SGD (Blanco et al., 2008; Welti et al., 2015). Furthermore, indirect estimates - based on the product of solute concentrations in fresh inland groundwater and SGD flux estimates based on isotopic tracers or hydraulic gradients - are more often used to obtain a spatially integrated estimate of chemical discharge (Beck et al., 2011; Burnett et al., 2006), though they often ignore transformations occurring in surface sediments at the seep- 
age face (Rao and Charette, 2012). Integrating the role of in situ $\mathrm{N}$ transformations is also critical to accurately estimating the impact that coastal boreal systems have on regional and global nutrient budgets. Here, the potential nutrient export from the STE at Martinique Beach to the seepage face has been calculated based on Darcy's flow through the $50 \mathrm{~m}$ length of the STE reported by Chaillou et al. (2016). To estimate the potential nitrogen export to the seepage face, we assumed that the TDN produced in the Martinique Beach STE is flushed out of the system by the continental hydraulic gradient.

This potential $\mathrm{N}$ export corresponds to $141,1.3$ and $33.8 \mathrm{~mol} \mathrm{~m}^{-1} \mathrm{yr}^{-1}$ for $\mathrm{NH}_{4}^{+}, \mathrm{NO}_{x}$ and DON respectively (Table 3), corresponding to an annual $\mathrm{N}$ input of $\sim 3100 \mathrm{~kg}$ along the $1200 \mathrm{~m}$ Martinique Beach shoreline, which is twice the groundwater-borne fluxes. DIN exported to the seepage face $\left(\sim 142 \mathrm{~mol} \mathrm{~m}^{-1} \mathrm{yr}^{-1}\right)$ was in the range of previous measurements at other sites, such as the Mediterranean coast (France; $530 \mathrm{~mol} \mathrm{~m}^{-1} \mathrm{yr}^{-1}$; Weinstein et al., 2011), the Gulf of Mexico (FL, USA; $414 \mathrm{~mol} \mathrm{~m}^{-1} \mathrm{yr}^{-1}$; Santos et al., 2009) and the Atlantic coast (Aquitania coast, France; 150 $\mathrm{mol} \mathrm{m}^{-1} \mathrm{yr}^{-1}$; Anschutz et al., 2016). However, in most of these studies, the DIN pool was mainly dominated by $\mathrm{NO}_{x}$, while at Martinique Beach $\mathrm{NH}_{4}^{+}$represented more than $90 \%$ of the potential DIN supply to the seepage face. It is noteworthy that fewer studies report $\mathrm{NH}_{4}^{+}$as the main $\mathrm{N}$ species exported to the coastal ocean compared to $\mathrm{NO}_{x}$. Kroeger et al. (2007) showed high proportions of $\mathrm{NH}_{4}^{+}$and DON in SGD fluxes to Tampa Bay (FL, USA), which may be explained in part by historical eutrophication, local hypoxia and anoxia in this area (Janicki et al., 2001). Measurements of DON flux to the coastal ocean are scarce. Kim et al. (2013) reported conservative mixing of DON, with export fluxes of $1.31 \times 10^{5} \mathrm{~mol} \mathrm{~d}^{-1}$ in Hwasun Bay (Jeju Island, Korea) and in the Gulf of Mexico; Santos et al. (2009) estimated that land-derived DON makes up $\sim 52 \%$ of the total $\mathrm{N}$ exported to the coastal ocean.

It is difficult to estimate $\mathrm{N}$ fluxes by SGD to Martinique Bay, as coupled nitrification-denitrification in the upper 5$10 \mathrm{~cm}$ of sediments at the seepage face may remove much of the TDN flux exported from the STE (Gao et al., 2009; Gihring et al., 2010; Rao et al., 2008). Since $\mathrm{NH}_{4}^{+}$and DON are $\mathrm{N}$ species highly bioavailable to microorganisms, this $\mathrm{N}$ export can further be directly transformed by the microphytobenthos and higher trophic levels (Miller and Ullman, 2004). While fresh inland groundwater provides little input of $\mathrm{N}$ to Martinique Beach, biogeochemical processes in the beach groundwater lead to the transformation of organic $\mathrm{N}$ to inorganic $\mathrm{N}$. These biogeochemical processes affect the $\mathrm{N}$ species potentially discharged to the coastal ocean. This $\mathrm{N}$ supply from the beach groundwater could therefore change the local benthic biogeochemical cycles and associated communities (Sawyer, 2015; Welti et al., 2015).

\section{Conclusion}

This study highlights the role of the STE in processing groundwater-derived $\mathrm{N}$ in a shallow boreal STE, far from anthropogenic pressures. $\mathrm{N}$ was mobilized within the STE since in situ production of $\mathrm{NH}_{4}^{+}$and $\mathrm{DON}$ were observed in beach groundwater. Fresh inland groundwaters delivered to the STE are rich in $\mathrm{NO}_{x}$ and DON and depleted in $\mathrm{NH}_{4}^{+}$. DON represented the main $\mathrm{N}$ species along the flow path. However, a shift from $\mathrm{NO}_{x}$ to $\mathrm{NH}_{4}^{+}$occurred due to the removal of $\mathrm{NO}_{x}$ and the addition of $\mathrm{NH}_{4}^{+}$within the STE. Nitrate loss along the flow path could be attributed to alternative reduction pathways such as $\mathrm{Fe}$ oxidation and to the mineralization of OC, since DOC concentrations were high in the STE. A part of $\mathrm{NH}_{4}^{+}$production could be attributed to mineralization of DON. The increase of TDN (i.e. the sum of DON and $\mathrm{NH}_{4}^{+}$) in beach groundwater is likely the result of release of $\mathrm{N}$ from particulate organic matter of terrestrial origin. As a consequence, TDN in beach groundwater was higher than the inland fresh groundwater, revealing the reactivity of the system. While the input of $\mathrm{NO}_{x}$ represents $32 \%$ $\left(37 \mathrm{mmol} \mathrm{m}^{-1} \mathrm{yr}^{-1}\right.$ ) of the fresh groundwater input of TDN to the STE, $\mathrm{NO}_{x}$ fluxes potentially exported from the STE to the seepage face only represent $1 \%$ of the total exported TDN. Thus, near the discharge zone, $\mathrm{NH}_{4}^{+}$and DON dominated the TDN load exported to surface sediments and Martinique Bay. This local export of bioavailable $\mathrm{N}$ is probably removed in surface sediments, or it supports benthic production and higher trophic levels. This study highlights the impact of biogeochemical transformations on $\mathrm{N}$ species in a boreal STE. Our study showed that biogeochemical transformations, along a continuum between fresh inland groundwater and the ocean, modify the distribution of $\mathrm{N}$ species, providing new $\mathrm{N}$ species from terrestrial origin to the coastal ocean. These biogeochemically active and dynamic systems reflect the challenge of accurately estimating groundwater nutrient fluxes to the coastal ocean.

Data availability. All the data resulting from this study are available from the authors upon request (mathilde.couturier@uqar.ca).

Competing interests. The authors declare that they have no conflict of interest.

Acknowledgements. The authors wish to thank Fréderike LemayBorduas for her help in the field, Claude and Katia Bourque for access to the beach, and Laure Devine for the revision of the English phrasing. Two anonymous referees are gratefully thanked for their thoughtful and constructive comments on the original manuscript. This research was supported by the Canada Research Chair Program, grants from the Natural Sciences and Engineering 
Research Council of Canada to Gwénaëlle Chaillou and the Université du Québec à Rimouski. Partial funding was provided by Québec-Océan to Mathilde Couturier.

Edited by: Caroline P. Slomp

Reviewed by: two anonymous referees

\section{References}

Abarca, E., Karam, H., Hemond, H. F., and Harvey, C. F.: Transient groundwater dynamics in a coastal aquifer: the effects of tides, the lunar cycle and the beach profile, Water Resour. Res., 49, 2473-2488, https://doi.org/10.1002/wrcr.20075, 2013.

Aller, R. C.: Bioturbation and remineralization of sedimentary organic matter: effects of redox oscillation, Chem. Geol., 114, 331345, https://doi.org/10.1016/0009-2541(94)90062-0, 1994.

Anderson, D. M., Burkholder, J. M., Cochlan, W. P., Gobler, C. J., Heil, C. A., Kudela, R. M., Parsons, M. L., Rensel, J. E. J., Townsend, D. W., Trainer, V. L., and Vargo, G. A.: Harmful algal blooms and eutrophication: examining linkages from selected coastal regions of the United States, Harmful Algae, 8, 39-53, https://doi.org/10.1016/j.hal.2008.08.017, 2008.

Anschutz, P., Jorissen, F. J., Chaillou, G., Abu-Zied, R., and Fontanier, C.: Recent turbidite deposition in the eastern Atlantic: early diagenesis and biotic recovery, J. Mar. Res., 60, 835-854, https://doi.org/10.1357/002224002321505156, 2002.

Anschutz, P., Charbonnier, C., Deborde, J., Deirmendjian, L., Poirier, D., Mouret, A., Buquet, D., and Lecroart, P.: Terrestrial groundwater and nutrient discharge along the 240-km-long Aquitanian coast, Mar. Chem., 185, 38-47, https://doi.org/10.1016/j.marchem.2016.04.002, 2016.

Baker, M. A. and Vervier, P.: Hydrological variability, organic matter supply and denitrification in the Garonne River ecosystem, Freshwater Biol., 49, 181-190, https://doi.org/10.1046/j.13652426.2003.01175.x, 2004.

Beck, A. J., Tsukamoto, Y., Tovar-Sanchez, A., HuertaDiaz, M., Bokuniewicz, H. J., and Sanudo-Wilhelmy, S. A.: Importance of geochemical transformations in determining submarine groundwater discharge-derived trace metal and nutrient fluxes, Appl. Geochem., 22, 477-490, https://doi.org/10.1016/j.apgeochem.2006.10.005, 2007.

Beck, M., Riedel, T., Graue, J., Köster, J., Kowalski, N., Wu, C. S., Wegener, G., Lipsewers, Y., Freund, H., Böttcher, M. E., Brumsack, H.-J., Cypionka, H., Rullkötter, J., and Engelen, B.: Imprint of past and present environmental conditions on microbiology and biogeochemistry of coastal Quaternary sediments, Biogeosciences, 8, 55-68, https://doi.org/10.5194/bg-8-55-2011, 2011.

Beusen, A. H. W., Slomp, C. P., and Bouwman, A. F.: Global landocean linkage: direct inputs of nitrogen to coastal waters via submarine groundwater discharge, Environ. Res. Lett., 8, 34035, doi:1748-9326/8/3/034035, 2013.

Blanco, A. C., Nadakoa, K., and Yamamoto, T.: Planktonic and benthic microalgal community composition as indicators of terrestrial influence on a fringing reef in Ishigaki Island, Southwest Japan, Mar. Environ. Res., 66, 520-535, https://doi.org/10.1016/j.marenvres.2008.08.005, 2008.

Burnett, W., Aggarwal, P., Aureli, A., Bokuniewicz, H., Cable, J., Charette, M. A., Kontar, E., Krupa, S., Kulkarni,
K., Loveless, A., Moore, W., Oberdorfer, J., Oliveira, J., Ozyurt, N., Povinec, P., Privitera, A., Rajar, R., Ramessur, R., Scholten, J., Stieglitz, T., Taniguchi, M., and Turner, J.: Quantifying submarine groundwater discharge in the coastal zone via multiple methods, Sci. Total Environ., 367, 498-543, https://doi.org/10.1016/j.scitotenv.2006.05.009, 2006.

Chaillou, G., Anschutz, P., Dubrulle, C. and Lecroart, P.: Transient states in diagenesis following the deposition of a gravity layer: dynamics of $\mathrm{O}_{2}, \mathrm{Mn}, \mathrm{Fe}$ and $\mathrm{N}$-species in experimental units, Aquat. Geochem., 13, 157-172, https://doi.org/10.1007/s10498007-9013-0, 2007.

Chaillou, G., Touchette, M., Rémillard, A., Buffin-Bélanger, T., StLouis, R., Hétu, B., and Tita, G.: Synthèse de l'état des connaissances sur les eaux souterraines aux Îles-de-la-Madeleine Impacts de l'exploration et de l'exploitation des ressources naturelles sur celles-ci, Université du Québec à Rimouski, 2012.

Chaillou, G., Couturier, M., Tommi-Morin, G., and Rao, A. M.: Total alkalinity and dissolved inorganic carbon production in groundwaters discharging through a sandy beach, Procedia Earth Planet. Sci., 10, 88-99, https://doi.org/10.1016/j.proeps.2014.08.017, 2014.

Chaillou, G., Lemay-Borduas, F., and Couturier, M.: Transport and transformations of groundwater-borne carbon discharging through a sandy beach to coastal ocean, Can. Water Resour. J., 38, 809-828, https://doi.org/10.1080/07011784.2015.1111775, 2016.

Chaillou, G., Lemay-Borduas, F., Larocque, M., Couturier, M., Biehler, A., and Tommi-Morin, G.: Flow and discharge of groundwater from a snowmelt-affected sandy beach, J. Hydrol., in revision, 2017.

Couturier, M., Nozais, C., and Chaillou, G.: Microtidal subterranean estuaries as a source of fresh terrestrial dissolved organic matter to coastal ocean, Mar. Chem., 186, 46-57, https://doi.org/10.1016/j.marchem.2016.08.001, 2016.

Erler, D. V, Santos, I. R., Zhang, Y., Tait, D. R., Befus, K. M., Hidden, A., Li, L., and Eyre, B. D.: Nitrogen transformations within a tropical subterranean estuary, Mar. Chem., 164, 38-47, https://doi.org/10.1016/j.marchem.2014.05.008, 2014.

Gao, H., Schreiber, F., Collins, G., Jensen, M. M., Kostka, J. E., Lavik, G., de Beer, D., Zhou, H., and Kuypers, M. M.: Aerobic denitrification in permeable Wadden Sea sediments, ISME J., 4, 417-426, https://doi.org/10.1038/ismej.2009.127, 2009.

Gehrels, W. R.: Determining relative sea-level change from saltmarsh foraminifera and plant zones on the coast of Maine, USA, J. Coastal Res., 10, 990-1009, 1994.

Gihring, T. M., Canion, A., Riggs, A., Huettel, M., and Kostka, J. E.: Denitrification in shallow, sublittoral Gulf of Mexico permeable sediments, Limnol. Oceanogr., 55, 43-54, https://doi.org/10.4319/lo.2010.55.1.0043, 2010.

Glibert, P. M., Icarus Allen, J., Artioli, Y., Beusen, A., Bouwman, L., Harle, J., Holmes, R., and Holt, J.: Vulnerability of coastal ecosystems to changes in harmful algal bloom distribution in response to climate change: projections based on model analysis, Glob. Change Biol., 20, 3845-3858, https://doi.org/10.1111/gcb.12662, 2014.

Gonneea, M. E. and Charette, M. A.: Hydrologic controls on nutrient cycling in an unconfined coastal aquifer, Environ. Sci. Technol., 48, 14178-14185, https://doi.org/10.1021/es503313t, 2014. 
Gonneea, M. E., Mulligan, A. E., and Charette, M. A.: Climatedriven sea level anomalies modulate coastal groundwater dynamics and discharge, Geophys. Res. Lett., 40, 2701-2706, https://doi.org/10.1002/grl.50192, 2013.

Hall, P. J. and Aller, R. C.: Rapid, small-Volume, flow injection analysis for $\mathrm{CO}_{2}$ and $\mathrm{NH}_{4}+$ in marine and freshwaters, Limnol. Oceanogr., 37, 1113-1119, 1992.

Hansell, D. A. and Carlson, C. A.: Biogeochemistry of marine dissolved organic matter, Academic Press, Elsevier, San Diego, Ca, USA, 2014.

Heiss, J. W. and Michael, H. A.: Saltwater-freshwater mixing dynamics in a sandy beach aquifer over tidal, srpingneap and seasonal cycles, Water Resour. Res., 50, 6747-6766, https://doi.org/10.1002/2014WR015574, 2014.

Hinzman, L. D., Bettez, N. D., Bolton, W. R., Chapin, F. S., Dyurgerov, M. B., Fastie, C. L., Griffith, B., Hollister, R. D., Hope, A., Huntington, H. P., Jensen, A. M., Jia, G. J., Jorgenson, T., Kane, D. L., Klein, D. R., Kofinas, G., Lynch, A. H., Lloyd, A. H., Mcguire, A. D., Nelson, F. E., Oechel, W. C., Osterkamp, T. E., Racine, C. H., Romanovsky, V. E., Stone, R. S., Stow, D. A., Sturm, M., Tweedie, C. E., Vourlitis, G. L., Walker, M. D., Walker, D. A., Webber, P. J., Welker, J. M., Winker, K. S., and Yoshikawa, K.: Evidence and implications of recent climate change in northern Alaska and other Arctic regions, Clim. Change, 72, 251-298, https://doi.org/10.1007/s10584-005-53522, 2005.

Howarth, R. W. and Marino, R.: Nitrogen as the limiting nutrient for eutrophication in coastal marine ecosystems: evolving views over three decades, Limnol. Oceanogr., 51, 364-376, https://doi.org/10.4319/lo.2006.51.1_part_2.0364, 2006.

Hulth, S., Aller, R. C., and Gilbert, F.: Coupled anoxic nitrification/manganese reduction in marine sediments, Geochim. Cosmochim. Ac., 63, 49-66, https://doi.org/10.1016/S00167037(98)00285-3, 1999.

Hyacinthe, C., Anschutz, P., Carbonel, P., Jouanneau, J. M., and Jorissen, F. J.: Early diagenetic processes in the muddy sediments of the bay of biscay, Mar. Geol., 177, 111-128, https://doi.org/10.1016/S0025-3227(01)00127-X, 2001.

Jackson, N., Nordstrom, K., Smith, D., and Virginia, W.: Geomorphic - biotic interactions on beach foreshores in estuaries, J. Coastal Res., 424, 414-424, doi:0749-0208, 2002.

Janicki, A., Pribble, R., Janicki, S., and Winowitch, M.: An analysis of long-term trends in Tampa Bay water quality, Tampa Bay Estuary Program, St Petersburg, FL, USA, 2001.

Johannes, R. E.: The ecological significance of the submarine discharge of groundwater, Mar. Ecol.-Prog. Ser., 3, 365-373, 1980.

Jørgensen, L., Lechtenfeld, O. J., Benner, R., Middelboe, M., and Stedmon, C. A.: Production and transformation of dissolved neutral sugars and amino acids by bacteria in seawater, Biogeosciences, 11, 5349-5363, https://doi.org/10.5194/bg-115349-2014, 2014.

Juneau, M.-N.: Hausse récente du niveau marin relatif aux Îles de la Madeleine, Master's thesis, Université du Québec à Rimouski, Rimouski, Canada, 2012.

Kelaher, B. and Levinton, J.: Variation in detrital enrichment causes spatio-temporal variation in softsediment assemblages, Mar. Ecol.-Prog. Ser., 261, 85-97, https://doi.org/10.3354/meps261085, 2003.
Kim, T., Kwon, E., Kim, I., Lee, S., and Kim, G.: Dissolved organic matter in the subterranean estuary of a volcanic island, Jeju: importance of dissolved organic nitrogen fluxes to the ocean, J. Sea Res., 78, 18-24, https://doi.org/10.1016/j.seares.2012.12.009, 2013.

Knee, K. L. and Jordan, T. E.: Spatial distribution of dissolved radon in the Choptank river and its tributaries: implications for groundwater discharge and nitrate inputs, Estuar. Coast., 36, 12371252, 2013.

Korom, S. F.: Natural denitrification in the saturated zone: a review, Water Resour. Res., 28, 1657-1668, https://doi.org/10.1029/92WR00252, 1992.

Kroeger, K. D. and Charette, M.: Nitrogen biogeochemistry of submarine groundwater discharge, Limnol. Oceanogr., 53, 10251039, 2008.

Kroeger, K. D., Cole, M. L., and Valiela, I.: Groundwatertransported dissolved organic nitrogen exports from coastal watersheds, Limnol. Oceanogr., 51, 2248-2261, https://doi.org/10.4319/lo.2006.51.5.2248, 2006.

Kroeger, K. D., Swarzenski, P. W., Greenwood, W. J., and Reich, C.: Submarine groundwater discharge to Tampa Bay: nutrient fluxes and biogeochemistry of the coastal aquifer, Mar. Chem., 104, 8597, https://doi.org/10.1016/j.marchem.2006.10.012, 2007.

Loveless, A. M. and Oldham, C. E.: Natural attenuation of nitrogen in groundwater discharging through a sandy beach, Biogeochemistry, 98, 75-87, https://doi.org/10.1007/s10533-009-9377$\mathrm{x}, 2010$.

Madelin'Eau: Gestion des eaux souterraines aux Îles-de-laMadeleine Un défi de développement durable Rapport final, 2004.

Madelin'Eau: Secteur sud-est de l'île de grande entrée - Rapport hydrologique, 2007.

Madelin'Eau: Secteur de grande-entrée - flanc nord alimentation en eau potable, 2009.

Madelin'Eau: Projet de réalisation d'un forage gazier vertical et conventionel d'une profondeur de $2500 \mathrm{~m}$, municipalité des îles de la Madeleine - Rapport d'étape 1, expertise hydrogéologique, 2011.

Martin, J. B., Hartl, K. M., Corbett, D. R., Swarzenski, P. W., and Cable, J. E.: A multi-level pore-water sampler for permeable sediments, J. Sediment. Res., 73, 128-132, https://doi.org/10.1306/070802730128, 2003.

Masselink, G. and Short, A.: The effect on tide range on beach morphodynamics and morphology: a conceptual beach model, J. Coastal Res., 9, 785-800, 1993.

McCoy, C. and Corbett, D. R.: Review of submarine groundwater discharge (SGD) in coastal zones of the Southeast and Gulf Coast regions of the United States with management implications, J. Environ. Manage., 90, 644-51, https://doi.org/10.1016/j.jenvman.2008.03.002, 2009.

Miller, D. C. and Ullman, W. J.: Ecological consequences of ground water discharge to Delaware Bay, United States, Groundwater, 42(, 959-970, https://doi.org/10.1111/j.17456584.2004.tb02635.x, 2004.

Moore, W. S.: The subterranean estuary: a reaction zone of ground water and sea water, Mar. Chem., 65, 111-125, https://doi.org/10.1016/S0304-4203(99)00014-6, 1999. 
Moore, W. S.: The effect of submarine groundwater discharge on the ocean., Ann. Rev. Mar. Sci., 2, 59-88, https://doi.org/10.1146/annurev-marine-120308-081019, 2010.

Null, K. A., Dimova, N. T., Knee, K. L., Esser, B. K., Swarzenski, P. W., Singleton, M. J., Stacey, M., and Paytan, A.: Submarine groundwater discharge-derived nutrient loads to San Francisco bay: implications to future ecosystem changes, Estuar. Coast., 35, 1299-1315, https://doi.org/10.1007/s12237012-9526-7, 2012.

Postma, D.: Kinetics of nitrate reduction by detrital Fe (II)-silicates, Geochim. Cosmochim. Ac., 54, 903-908, 1990.

Postma, D., Boesen, C., Kristiansen, H., and Larsen, F.: Nitrate reduction in an unconfined sandy aquifer: water chemistry, reduction processes and geochemical modeling, Water Resour. Res., 27, 2027-2045, https://doi.org/10.1029/91WR00989, 1991.

Rao, A. M. F. and Charette, M. A.: Benthic nitrogen fixation in an eutrophic estuary affected by groundwater discharge, J. Coastal Res., 280, 477-485, https://doi.org/10.2112/JCOASTRES-D-11$00057.1,2012$.

Rao, A. M. F., McCarthy, M. J., Gardner, W. S., and Jahnke, R. A.: Respiration and denitrification in permeable continental shelf deposits on the South Atlantic Bight: N2: Ar and isotope pairing measurements in sediment column experiments, Cont. Shelf Res., 28, 602-613, 2008.

Rivett, M. O., Buss, S. R., Morgan, P., Smith, J. W. N., and Bemment, C. D.: Nitrate attenuation in groundwater: A review of biogeochemical controlling processes, Water Res., 42, 4215-4232, https://doi.org/10.1016/j.watres.2008.07.020, 2008.

Robinson, C., Li, L., and Barry, D. A.: Effect of tidal forcing on a subterranean estuary, Adv. Water Resour., 30, 851-865, https://doi.org/10.1016/j.advwatres.2006.07.006, 2007a.

Robinson, C., Xin, P., Li, L., and Barry, D. A.: Groundwater flow and salt transport in a subterranean estuary driven by intensified wave conditions, Water Resour. Res., 50, 165-181, https://doi.org/10.1002/2013WR013813, 2014.

Rocha, C., Ibanhez, J., and Leote, C.: Benthic nitrate biogeochemistry affected by tidal modulation of Submarine Groundwater Discharge (SGD) through a sandy beach face, Ria Formosa, Southwestern Iberia, Mar. Chem., 115, 43-58, https://doi.org/10.1016/j.marchem.2009.06.003, 2009.

Rocha, C., Wilson, J., Scholten, J., and Schubert, M.: Retention and fate of groundwater-borne nitrogen in a coastal bay (Kinvara Bay, Western Ireland) during summer, Biogeochemistry, 125, 275299, https://doi.org/10.1007/s10533-015-0116-1, 2015.

Rossi, F., Incera, M., Callier, M., and Olabarria, C.: Effects of detrital non-native and native macroalgae on the nitrogen and carbon cycling in intertidal sediments, Mar. Biol., 158, 2705-2715, https://doi.org/10.1007/s00227-011-1768-6, 2011.

Sáenz, J. P., Hopmans, E. C., Rogers, D., Henderson, P. B., Charette, M. A., Schouten, S., Casciotti, K. L., Sinninghe Damsté, J. S., and Eglinton, T. I.: Distribution of anaerobic ammonia-oxidizing bacteria in a subterranean estuary, Mar. Chem., 136, 7-13, https://doi.org/10.1016/j.marchem.2012.04.004, 2012.

Santoro, A. E.: Microbial nitrogen cycling at the saltwaterfreshwater interface, Hydrogeol. J., 18, 187-202, https://doi.org/10.1007/s10040-009-0526-z, 2010.

Santos, I., Burnett, W. C., Dittmar, T., Suryaputra, I. G. N., and Chanton, J.: Tidal pumping drives nutrient and dissolved organic matter dynamics in a Gulf of Mexico subter- ranean estuary, Geochim. Cosmochim. Ac., 73, 1325-1339, https://doi.org/10.1016/j.gca.2008.11.029, 2009.

Santos, I., Eyre, B. D., and Huettel, M.: The driving forces of porewater and groundwater flow in permeable coastal sediments: A review, Estuar. Coast. Shelf S., 98, 1-15, https://doi.org/10.1016/j.ecss.2011.10.024, 2012.

Santos, I. R., Burnett, W. C., Chanton, J., Mwashote, B., Suryaputra, I. G. N. A., and Dittmar, T.: Nutrient biogeochemistry in a Gulf of Mexico subterranean estuary and groundwater-derived fluxes to the coastal ocean, Limnol. Oceanogr., 53, 705-718, https://doi.org/10.4319/lo.2008.53.2.0705, 2008.

Santos, I. R., Bryan, K. R., Pilditch, C. A., and Tait, D. R.: Influence of porewater exchange on nutrient dynamics in two New Zealand estuarine intertidal flats, Mar. Chem., 167, 57-70, https://doi.org/10.1016/j.marchem.2014.04.006, 2014.

Sawyer, A. H.: Enhanced removal of groundwater-borne nitrate in heterogeneous aquatic sediments, Geophys. Res. Lett., 42, 403 410, https://doi.org/10.1002/2014GL062234, 2015.

Schlacher, T. A. and Connolly, R. M.: Land-ocean coupling of carbon and nitrogen fluxes on sandy beaches, Ecosystems, 12, 311321, https://doi.org/10.1007/s10021-008-9224-2, 2009.

Schnetger, B. and Lehners, C.: Determination of nitrate plus nitrite in small volume marine water samples using vanadium(III)chloride as a reduction agent, Mar. Chem., 160, 91-98, https://doi.org/10.1016/j.marchem.2014.01.010, 2014.

Scott, D. B., Brown, K., Collins, E. S., and Medioli, F. S.: A new sea-level curve from Nova Scotia: evidence for a rapid acceleration of sea-level rise in the late mid-Holocene, Can. J. Earth Sci., 32, 2071-2080, https://doi.org/10.1139/e95-160, 1995a.

Scott, D. B., Gayes, P. T., and Collins, E. S.: Mid-holocene precedent for a future rise in sea-level along the Atlantic coast of North America, J. Coastal Res., 11, 615-622, 1995b.

Seitzinger, S. P., Sanders, R. W., and Styles, R.: Bioavailability of DON from natural and anthropogenic sources to estuarine plankton, Limnol. Oceanogr., 47, 353-366, https://doi.org/10.4319/lo.2002.47.2.0353, 2002.

Seitzinger, S. P., Harrison, J. A., Dumont, E., Beusen, A. H. W., and Bouwman, A. F.: Sources and delivery of carbon, nitrogen and phosphorus to the coastal zone: an overview of global Nutrient Export from Watersheds (NEWS) models and their application, Global Biogeochem. Cy., 19, GB4S01, https://doi.org/10.1029/2005GB002606, 2005.

Sipler, R. E. and Bronk, D. A.: Dynamics of dissolved organic nitrogen, in: Biogeochemistry of marine dissolved organic matter, edited by: Hansell, D. A. and Carlson, C. A., 127-184, Academic Press, San Diego, Ca, USA, 2014.

Slomp, C. P. and Van Cappellen, P.: Nutrient inputs to the coastal ocean through submarine groundwater discharge: controls and potential impact, J. Hydrol., 295, 64-86, 2004.

Sundby, B.: Transient state diagenesis in continental margin muds, Mar. Chem., 102, 2-12, https://doi.org/10.1016/j.marchem.2005.09.016, 2006.

Talbot, J. M., Kroeger, K. D., Rago, A., Allen, M. C., and Charette, M. A.: Nitrogen flux and speciation through the subterranean estuary of Waquoit Bay, Massachusetts, Biol. Bull., 205, 244-245, https://doi.org/10.2307/1543276, 2003.

Valiela, I., Costa, J., Foreman, K., Teal, J. M., Howes, B., and Aubrey, D.: Transport of groundwater-borne nutrients from wa- 
tersheds and their effects on coastal waters, Biogeochemistry, 10, 177-197, 1990.

Voss, M., Bange, H. W., Dippner, J. W., Middelburg, J. J., Montoya, J. P., and Ward, B.: The marine nitrogen cycle: recent discoveries, uncertainties and the potential relevance of climate change, Philos. T. R. Soc., 368, https://doi.org/10.1098/rstb.2013.0121, 2013.

Weinstein, Y., Yechieli, Y., Shalem, Y., Burnett, W., Swarzenski, P. W., and Herut, B.: What is the role of fresh groundwater and recirculated seawater in conveying nutrients to the coastal ocean?, Environ. Sci. Technol., 45, 5195-5200, https://doi.org/10.1021/es104394r, 2011.
Welti, N., Gale, D., Hayes, M., Kumar, A., Gasparon, M., Gibbes, B. and Lockington, D.: Intertidal diatom communities reflect patchiness in groundwater discharge, Estuar. Coast. Shelf S., https://doi.org/10.1016/j.ecss.2015.06.006, 2015. 